\title{
Surface-Water Quality Changes After 5 Years of Nutrient Management in the Little Conestoga Creek Headwaters, Pennsylvania, 1989-91
}

U.S. GEOLOGICAL SURVEY

Water-Resources Investigations Report 97-4048

Prepared in cooperation with the

PENNSYLVANIA DEPARTMENT OF ENVIRONMENTAL PROTECTION, BUREAU OF LAND AND WATER CONSERVATION 


\section{Surface-Water Quality Changes After 5 Years of Nutrient Management in the Little Conestoga Creek Headwaters, Pennsylvania, 1989-91}

By Edward H. Koerkle and Linda C. Gustafson-Minnich

With a section on "Benthic Macroinvertebrates"

by Michael D. Bilger

U.S. GEOLOGICAL SURVEY

Water-Resources Investigations Report 97-4048

Prepared in cooperation with the

PENNSYLVANIA DEPARTMENT OF ENVIRONMENTAL PROTECTION, BUREAU OF LAND AND WATER CONSERVATION 


\title{
U.S. DEPARTMENT OF THE INTERIOR \\ BRUCE BABBITT, Secretary
}

\author{
U.S. GEOLOGICAL SURVEY \\ Gordon P. Eaton, Director
}

For additional information write to:

District Chief

U.S. Geological Survey

840 Market Street

Lemoyne, Pennsylvania 17043-1586
Copies of this report may be purchased from:

U.S. Geological Survey

Branch of Information Services

Box 25286

Denver, Colorado 80225-0286 


\section{Contents}

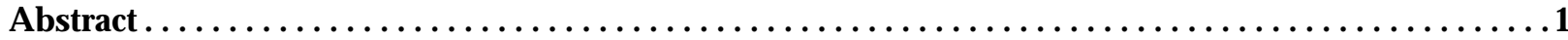

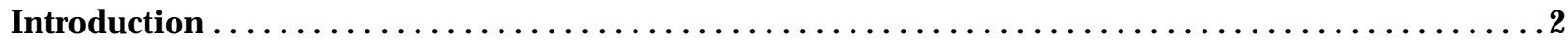

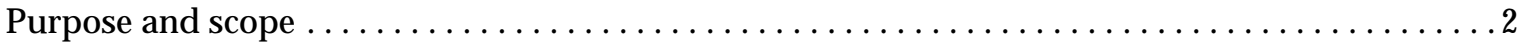

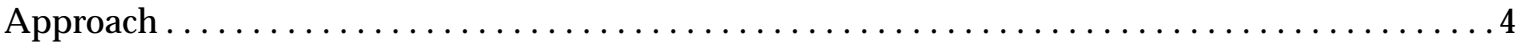

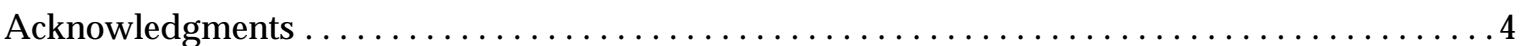

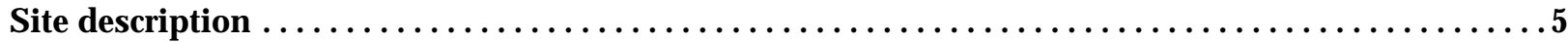

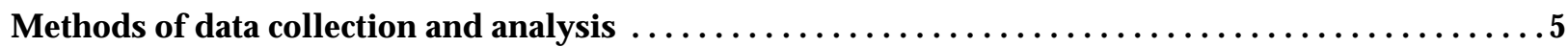

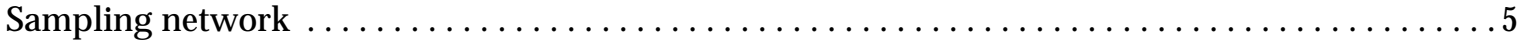

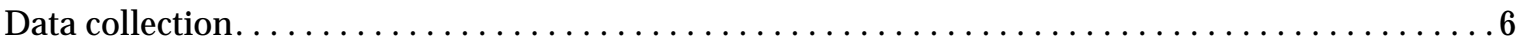

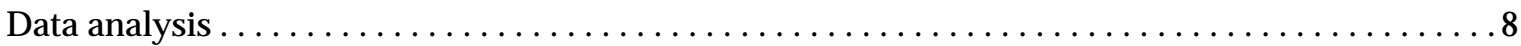

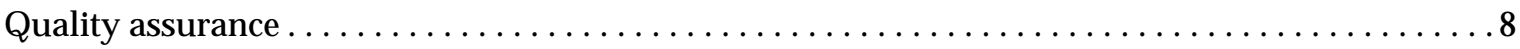

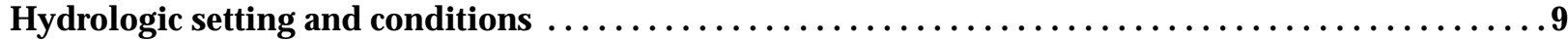

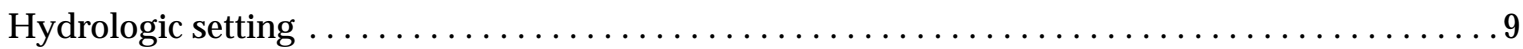

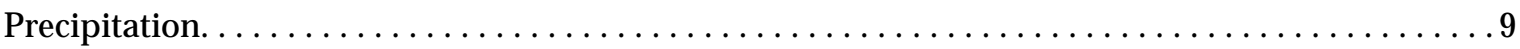

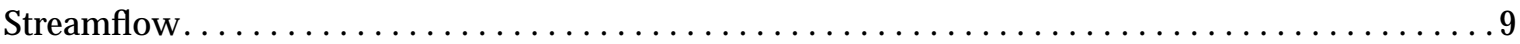

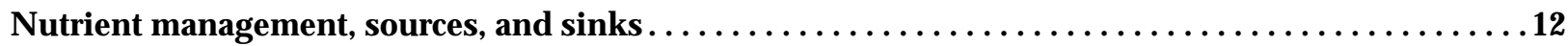

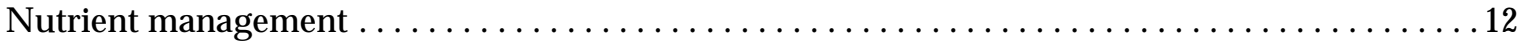

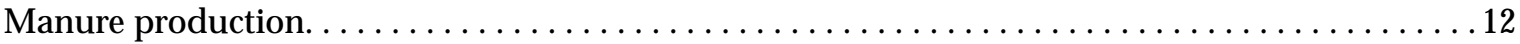

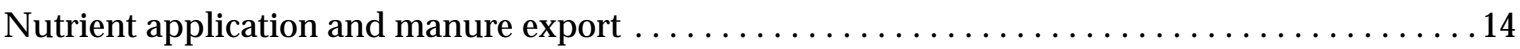

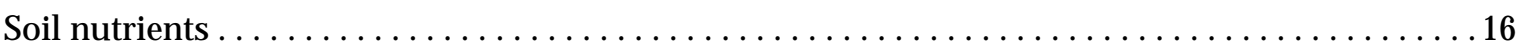

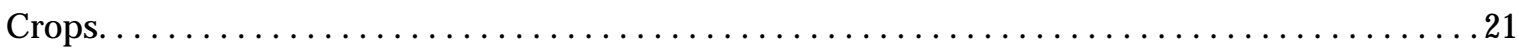

Changes in surface-water quality after nutrient management $\ldots \ldots \ldots \ldots \ldots \ldots \ldots \ldots \ldots \ldots \ldots \ldots$

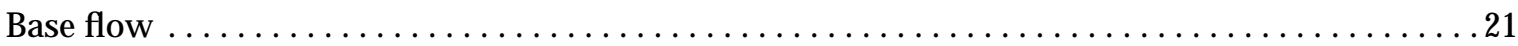

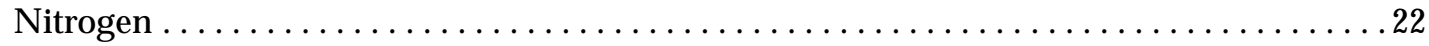

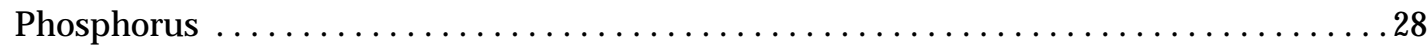

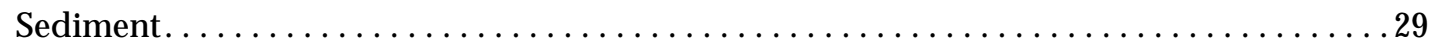

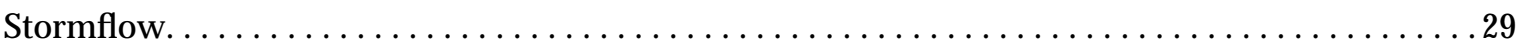

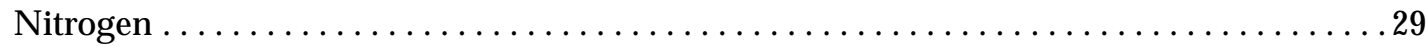

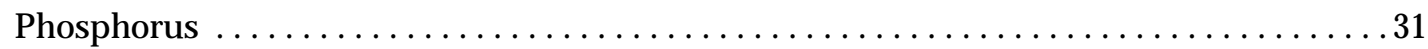

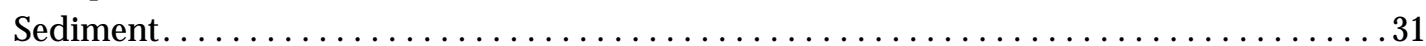

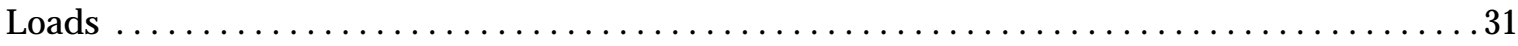

Benthic macroinvertebrates, by Michael D. Bilger, Biologist . . . . . . . . . . . . . . 35

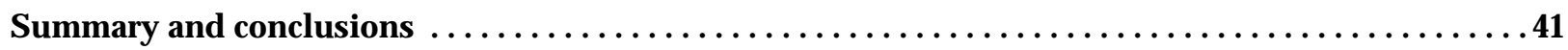

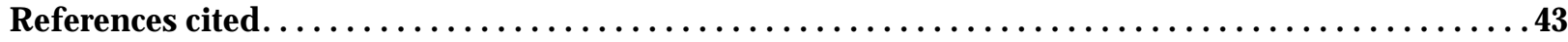




\section{Illustrations}

Figure 1. Map showing location of subbasins, farms, and data-collection sites within the Small Watershed, Lancaster and Berks Counties, Pennsylvania.............. 3

2-3. Graphs showing:

2. Monthly mean streamflow at site SW1 in the Small Watershed .......... 11

3. Monthly departure from average streamflow, in percent, and cumulative departure from average streamflow, in cubic feet per second, at site SW1 in the Small Watershed ......................... 11

4. Map showing distribution of nutrient-management plans in the Small

Watershed............................................ 13

5-7. Graphs showing:

5. Annual applications of nitrogen to cropland in the Nutrient-Management Subbasin of the Small Watershed ........................ 15

6. Amounts of soluble nitrate, as nitrogen, in the top 4 feet of soil prior to and during nutrient management at farms $\mathrm{D}, \mathrm{F}, \mathrm{H}$, and $\mathrm{M}$ in the Nutrient-Management Subbasin .................... 19

7. Amounts of soluble orthophosphorus, as phosphorus, in the top 4 feet of soil prior to and during nutrient management at farms D, F, H, and $\mathrm{M}$ in the Nutrient-Management Subbasin................ 20

8-9. Boxplots showing:

8. Concentrations of dissolved ammonium and dissolved nitrate plus nitrite in base flow at sites NM1, NM5, NC1, and SW1 in the Small Watershed from October 1989 through September $1991 \ldots \ldots \ldots \ldots \ldots . \ldots 23$

9. Concentrations of total ammonium plus organic nitrogen in base flow at sites NM1, NM5, NC1, and SW1 in the Small Watershed from October 1989 through September 1991

10-11. Graphs showing:

10. Relation between concentrations of dissolved nitrate plus nitrite in base flow from the Nutrient-Management Subbasin (NM5) and in base flow from the Nonnutrient-Management Subbasin (NC1) . . . . . . . . . . 26

11. Dissolved nitrate plus nitrite concentrations in base flow at sites NM1 and NM5 in the Nutrient-Management Subbasin, site NC1 in the Nonnutrient-Management Subbasin, and site SW1 in the Small Watershed.

12-14. Boxplots showing:

12. Concentrations of total phosphorus and suspended sediment in base flow at sites NM1, NM5, NC1, and SW1 in the Small Watershed from October 1989 through September $1991 \ldots \ldots \ldots \ldots \ldots \ldots \ldots \ldots . \ldots 28$

13. Mean concentrations of total nitrate plus nitrite, total ammonium plus organic nitrogen, total phosphorus, and suspended sediment in stormflow at site SW1 in the Small Watershed ........................ 30

14. Mean concentrations of total nitrate plus nitrite, total ammonium plus organic nitrogen, total phosphorus, and suspended sediment in stormflow at site NM5 in the Small Watershed ....................... 30

15. Graph showing monthly loads and monthly mean streamflow at site SW1 in the Small Watershed from April 1984 through September 1991 . . . . . . . . . . . 34 


\section{Tables}

Table 1. Land use in the Small Watershed, as percentage of total area.................. 5

2. Small Watershed study area surface-water data-collection stations. $\ldots \ldots \ldots \ldots \ldots \ldots \ldots$

3. Data-collection schedule for the Small Watershed study from October 1989 through

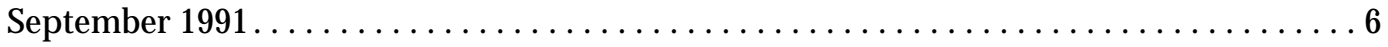

4. Physical characteristics and chemical constituents for which surface-water

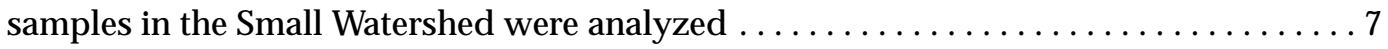

5. Monthly, annual, and period-of-record mean streamflow and mean base flow, in cubic feet per second, at sites SW1 and NM5 in the Small Watershed .......... 10

6. Percentage of agricultural land in the Small Watershed included under nutrientmanagement plans, September 1989 to September 1991 ........................ 14

7. Reported nutrient applications to cropland in the Small Watershed and NutrientManagement Subbasin, in pounds, for October 1989 through September 1991 . . . . . . . 14

8. Average annual nitrogen and phosphorus application rates, in pounds per acre of crop and pasture land, in the Small Watershed, Nutrient-Management Subbasin, and Nonnutrient-Management Subbasin for October 1989

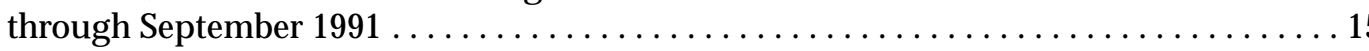

9. Average annual exports of nitrogen and phosphorus from the Small Watershed and Nutrient-Management Subbasin for October 1989 through September 1991 . . . . . . 16

10. Amounts of soluble nitrate nitrogen and orthophosphorus in soil samples from four farms in the Nutrient-Management Subbasin, in pounds per acre per

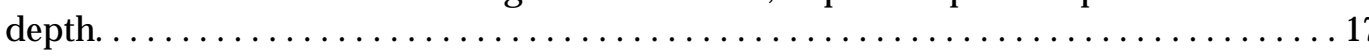

11. Amounts of ammonia and ammonia plus organic nitrogen in soil samples from four farms in the Nutrient-Management Subbasin, in pounds per acre per depth . . . . . . 18

12. Percentage of land use and crop coverage in the Small Watershed and Nutrient-Management Subbasin, 1989-91, and in the Nutrient-Management

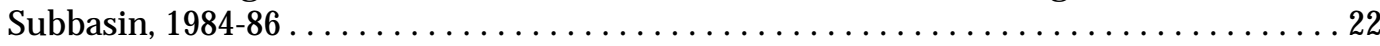

13. Results of seasonal Mann-Whitney rank-sum test for step trends from April 1984 through March 1986 to October 1989 through September 1991 in unadjusted and flow-adjusted concentrations of nutrient and suspended sediment in base flow in the Small Watershed . . . . . . . . . . . . . . . . . . . . . . . . . . 25

14. Results of Mann-Whitney rank-sum test of April 1984 to April 1986 (before nutrient management) and April 1989 to October 1991 mean concentrations of constituents during stormflow at sites SW1 and NM5 in the Small Watershed .............. 31

15. Monthly and annual nutrient and suspended-sediment loads in streamflow from the Small Watershed (site SW1) for the period October 1989 through September 1991

16. Monthly and annual nutrient and suspended-sediment loads in streamflow from the Nutrient-Management Subbasin (site NM5) for the period October 1989

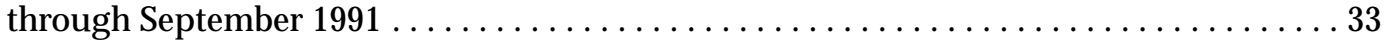

17. Benthic macroinvertebrates collected by Surber sampler in the Small Watershed ......... 36

18. Benthic macroinvertebrates collected by kick screen in the Small Watershed ............ 39 


\section{Conversion Factors and Abbreviated Water-Quality Units}

Length

$\begin{array}{lcl}\text { inch (in.) } & 2.54 & \text { centimeter } \\ \text { inch (in.) } & 25.4 & \text { millimeter } \\ \text { foot }(\mathrm{ft}) & 0.3048 & \text { meter } \\ \text { mile }(\mathrm{mi}) & 1.609 & \text { kilometer } \\ & \underline{\text { Area }} & \\ \text { acre } & 0.4047 & \text { hectare } \\ \text { square foot }\left(\mathrm{ft}^{2}\right) & 0.09294 & \text { square meter } \\ \text { square mile }\left(\mathrm{mi}^{2}\right) & 2.590 & \text { square kilometer } \\ & \underline{\text { Discharge }} & \\ \text { cubic foot per second }\left(\mathrm{ft}^{3} / \mathrm{s}\right) & 0.02832 & \text { cubic meter per second } \\ & \underline{\text { Mass }} & \\ \text { pound }(\mathrm{lb}) & 0.4545 & \text { kilogram } \\ \text { pound per acre }(\mathrm{lb} / \mathrm{acre}) & 1.123 & \text { kilogram per hectare } \\ & \underline{\text { Temperature }} & \\ \text { degree Fahrenheit }\left({ }^{\circ} \mathrm{F}\right) & { }^{\circ} \mathrm{C}=5 / 9\left({ }^{\circ} \mathrm{F}-32\right) & \text { degree Celsius }\end{array}$

Abbreviated water-quality units used in report:

$(\mu \mathrm{S} / \mathrm{cm})$ microsiemens per centimeter at 25 degrees Celsius $(\mathrm{mg} / \mathrm{L})$ milligrams per liter 


\title{
Surface-Water Quality Changes \\ After 5 Years of Nutrient Management in the Little Conestoga Creek Headwaters, Pennsylvania, 1989-91
}

\author{
By Edward H. Koerkle and Linda C. Gustafson-Minnich \\ With a section on "Benthic Macroinvertebrates" \\ by Michael D. Bilger
}

\begin{abstract}
A 5.82-square-mile drainage basin in the headwaters of the Little Conestoga Creek in Lancaster County, Pa., was investigated from October 1989 through September 1991 as part of a longer-term effort to determine the effects of nutrient management on surface-water quality. A previous investigation found no statistical evidence that implementation of nutrient management from 1986 to 1989 affected water quality. Basin land use is 68 percent agriculture and includes all or part of 51 farms. Agricultural land under nutrient management ranged from 55 percent in 1989 to 80 percent in 1991. Nitrate nitrogen, the dominant nonpoint-source contaminant, averaged about 7.5 milligrams per liter in base flow.

Implementation of nutrient management on 90 percent of applicable land in a 1.42-square-mile subbasin resulted in a 7 percent decrease in nitrogen applications from before nutrient management. Recognizing that some uncertainty exists in the nutrient-application data, the decrease consisted of a 44-percent decrease in commercial fertilizer nitrogen combined with a 3-percent increase in manure nitrogen applications. Manure accounted for 83 percent of the applied nitrogen. Amounts of nitrate nitrogen in the top 4 feet of soil ranged from 43 to 315 pounds per acre in the subbasin and were not substantially reduced from before nutrient management.

Statistical analysis of nutrient and suspended-sediment concentrations detected few significant step trends in water quality in a comparison with water quality before nutrient management. A decrease in base-flow concentrations of dissolved ammonium and suspended sediment was detected at a site draining a 1.43-square-mile subbasin with 40-percent implementation of nutrient-management plans. An increase in base-flow concentrations of suspended sediment was detected at a site draining the 1.42-square-mile subbasin with 90-percent implementation. A comparison of the dissolved nitrate plus nitrite in base-flow relations between paired subbasins detected no change from 1984-86 (before nutrient management) to 1989-91. Mean concentrations in stormflow were not reduced significantly from 1984-86 to 1989-91. Data collected during the entire 1986-91 nutrient-management period suggest a reduction in nitrogen input as large as the 30-percent reduction recorded from 1986-89 is needed to effect a 0.5-milligram-per-liter decrease in dissolved nitrate plus nitrite.
\end{abstract}




\section{INTRODUCTION}

From April 1984 to September 1989, a water-quality study was conducted to determine the effects of nutrient management, an agricultural Best-Management Practice (BMP), on water quality in a 5.82- $\mathrm{mi}^{2}$ drainage basin in the headwaters of the Little Conestoga Creek. Results of the study showed no statistically significant changes in base-flow and stormflow concentrations of nitrogen and phosphorus after 3.5 years of nutrient management. However, results of the study suggested that widespread use of nutrient management in one subbasin resulted in reduced concentrations of dissolved nitrate plus nitrite in stream base flow compared to a second paired subbasin having limited implementation of nutrient management (Koerkle and others, 1996).

The possibility that significant changes in water quality were delayed by reserves of leachable nitrogen in the heavily manured soils and masked by strong seasonal and climatic variation suggested that additional response time was needed. In order to permit additional time for depletion of excess nitrogen and for improved resolution of statistical tests, the study was extended for 2 additional years. Results of the 2-year continuation, completed by the U.S. Geological Survey (USGS) in cooperation with the Pennsylvania Department of Environmental Protection $(\mathrm{PaDEP})^{1}$, Bureau of Land and Water Conservation, are the subject of this report.

The 1984-89 study was completed in coordination with the U.S. Department of Agriculture (USDA), Conestoga River Headwaters Rural Clean Water Program (RCWP). The RCWP called for voluntary implementation of nutrient management and other BMP's to reduce nonpoint-source loads from the Conestoga River headwaters. Water quality in the Conestoga River Basin is characterized by large nonpoint-source loads of nutrients and suspended sediment primarily caused by intensive agriculture.

Nutrient management, for these studies, was defined as the combined practices of animal-waste management and fertilizer management as defined by the Agricultural Stabilization and Conservation Service (ASCS) of the USDA. With nutrient management, the rates and timing of applications of manure and commercial fertilizer are chosen to adequately supply crop nutrient needs and minimize the amount of unused nutrients that become available for transport to surface water and ground water.

Information on the Conestoga Headwaters RCWP project can be found in "Evaluation of Agricultural Best-Management Practices in the Conestoga River Headwaters, Pennsylvania: Methods of Data Collection and Analysis, and Description of Study Areas," by Chichester (1988); "Evaluation of Agricultural Best-Management Practices in the Conestoga River Headwaters, Pennsylvania: Description and Water Quality of the Little Conestoga Creek Headwaters Prior to the Implementation of Nutrient Management," by Fishel and others (1992); and in "Evaluation of Agricultural Best-Management Practices in the Conestoga River Headwaters, Pennsylvania: Effects of Nutrient Management on Water Quality in the Little Conestoga Creek Headwaters, 1983-1989," by Koerkle and others (1996).

\section{Purpose and Scope}

This report summarizes the results of an investigation of the effects of nutrient management on surface-water quality in a 5.82- $\mathrm{mi}^{2}$ drainage basin designated the Small Watershed in the Little Conestoga Creek headwaters (fig. 1). Presented are hydrologic, nutrient-management-implementation, agriculturalactivity, soil-nutrient, and benthic-macroinvertebrate data collected from October 1, 1989, through September 30,1991, the period of study. These data are compared to data collected at the same sites from April 1, 1984, through March 31, 1986, before nutrient management and, in some instances, to data collected from April 1, 1984, through September 30, 1989, before and during nutrient management. The effects of nutrient management on surface-water quality are evaluated through qualitative and statistically-based inferences. Emphasis in the evaluations is placed on nitrogen because it is the largest nutrient source in the Small Watershed and the nutrient addressed in nutrient-management plans. Specific comparisons include (1) before and after nutrient-management applications of manure and fertilizers, (2) before and after nutrient management base-flow and stormflow water quality, (3) among site comparisons of base-flow water quality, and (4) paired-subbasin comparison of dissolved nitrate plus nitrite.

\footnotetext{
${ }^{1}$ Prior to 1995, the Pennsylvania Department of Environmental Protection was known as the Pennsylvania Department of Environmental Resources.
} 


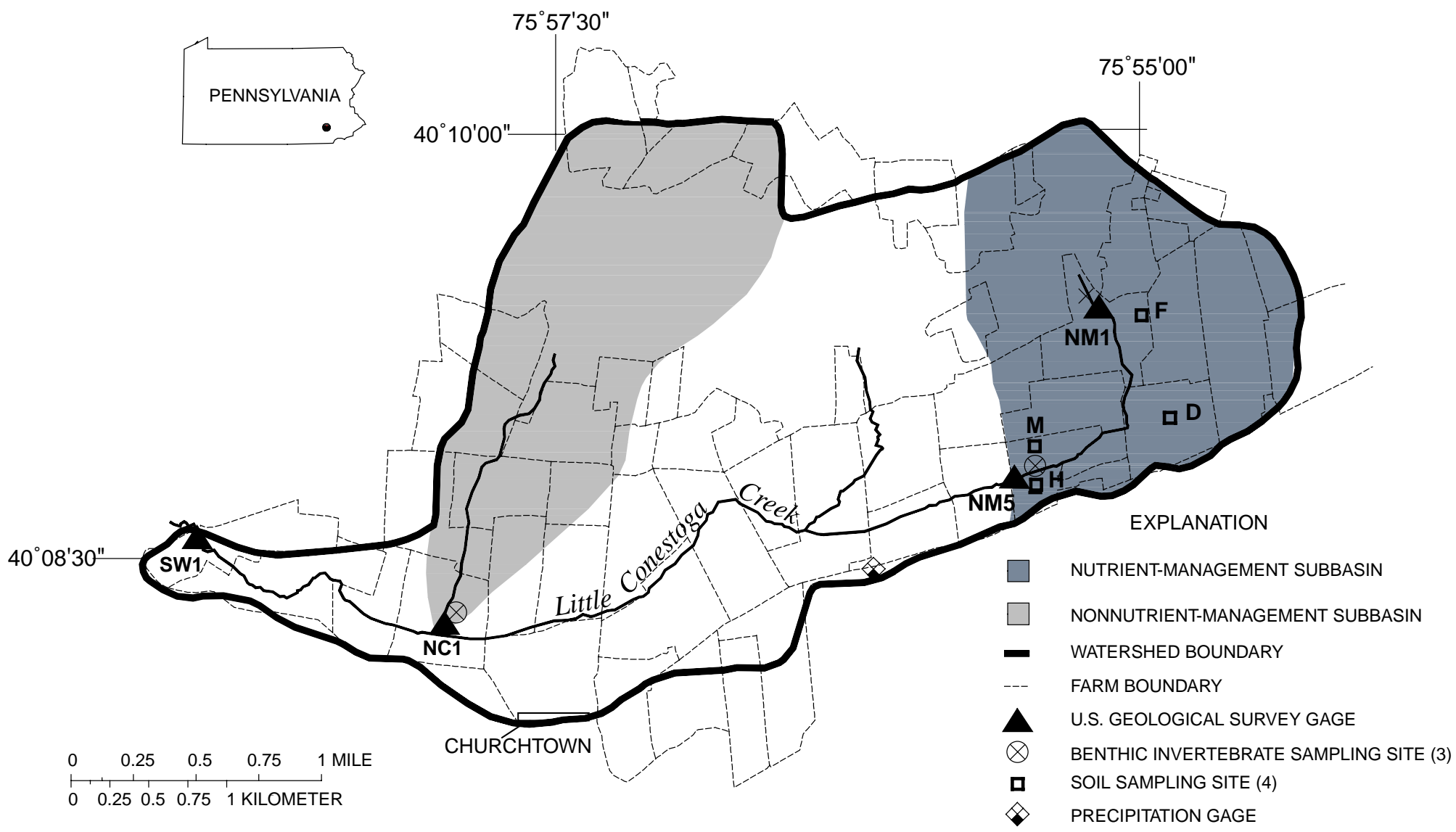

Figure 1. Location of subbasins, farms, and data-collection sites within the Small Watershed, Lancaster and Berks Counties, Pennsylvania. 


\section{Approach}

The Small Watershed study was conducted by use of a multiple basin pre- and post-treatment and paired-subbasins experimental design. This design, essentially identical to the RCWP study approach, was selected to allow aggregation of new data with data collected during the RCWP study. Aggregation of data enhanced the power of statistical tests to detect changes in water quality. The pre- and post-treatment experiment compared data collected before and after implementation of nutrient management to determine if change has occurred. Paired subbasins strengthen the experimental design by providing data from drainage basins similar in size and geologic, hydrologic, and agricultural characteristics except for the implementation of nutrient management. The paired subbasins (fig. 1) within the Small Watershed were delineated during the RCWP study as examples of areas having (1) high BMP implementation (Nutrient-Management Subbasin) and (2) little or no BMP implementation (Nonnutrient-Management Subbasin).

The Nonnutrient-Management Subbasin was intended to function as a control for the paired subbasins. A large percentage of farm operators in the subbasin chose at the beginning of the RCWP study not to adopt nutrient management and not to provide agricultural-activity information. However, unexpected changes in agricultural activities did occur. These changes in agricultural practices, in combination with no supporting data, add substantial uncertainty to the assumption that water-quality data from the Nonnutrient-Management Subbasin represents controlled, that is minimally changed, conditions.

\section{Acknowledgments}

The following individuals and their respective agencies are acknowledged for their assistance: (1) The farmers in the Small Watershed study area, for volunteering and assisting with project objectives and providing agricultural-activity data; (2) Omer Brubaker from the USDA, ASCS, for obtaining agricultural-activity data and making field inspections; (3) Leon Marshall from the Pennsylvania State University, Department of Agronomy, for the collection of soil samples; and (4) Leon Ressler and Jeff Stoltzfus from the Nutrient Management Office in New Holland, Pa., for preparing nutrient-management plans. 


\section{SITE DESCRIPTION}

The 5.82- $\mathrm{mi}^{2}$ Small Watershed is in parts of Lancaster and Berks Counties, south-central Pennsylvania (fig. 1), and lies in two sections of the Piedmont Physiographic Province. The northern half, in the Gettysburg-Newark Lowland Section, is underlain by conglomerate, mudstone, sandstone, shale, and diabase of Triassic age and is characterized by broad highlands and ridges. This area typically has thin, stony soils and moderate to steep slopes (Custer, 1985). The southern half, in the Piedmont Lowland Section, is characterized by rolling lowlands developed in Cambrian- and Ordovician-age carbonate rocks of the Buffalo Springs and Stonehenge Formations, respectively. Soils here are predominantly carbonate derived and are cited as prime farm land in the Lancaster County Soil Survey (Custer, 1985).

Agriculture is the predominant land use in the Small Watershed (table 1) and is concentrated in the southern half of the basin. Forested land is predominant in the northern half of the basin where soils are mostly unsuitable for agriculture. Urban land is concentrated in and near Churchtown, which is along the southern boundary of the study area. Residential housing is sparsely scattered throughout the study area. The Little Conestoga Creek, which drains the Small Watershed, is in a carbonate valley that dominates the southern half of the drainage basin. About 95 percent of the stream reach within the Small Watershed is bordered by land used for agriculture. Land directly next to the stream is used almost exclusively for pasturing.

The Small Watershed contained all or part of 51 farms (fig. 1) that accounted for 2,500 acres out of a total basin acreage of 3,720 acres. Average farm size was about 50 acres. Both animals and row crops were raised. Dairy cows were the predominant animal type, and corn was the predominant row crop. The

$1.42-\mathrm{mi}^{2}$ Nutrient-Management Subbasin contained all or part of 16 farms covering 710 acres. The 1.43-mi ${ }^{2}$ Nonnutrient-Management Subbasin contained all or part of 13 farms covering 490 acres.

Table 1. Land use in the Small Watershed, as percentage of total area

[From Koerkle and others, 1996.]

\begin{tabular}{lccc}
\hline \multirow{2}{*}{ Land use } & \multirow{2}{*}{$\begin{array}{c}\text { Small } \\
\text { Watershed } \\
\text { overall }\end{array}$} & $\begin{array}{c}\text { Nutrient- } \\
\text { Management }\end{array}$ & $\begin{array}{c}\text { Nonnutrient- } \\
\text { Management }\end{array}$ \\
\cline { 3 - 4 } & 68 & 78 & 59 \\
Agriculture & 24 & 21 & 40 \\
Forest & 8 & 1 & 1 \\
Urban & & & \\
\hline
\end{tabular}

\section{METHODS OF DATA COLLECTION AND ANALYSIS}

Methods of investigation, adapted from the RCWP studies, are discussed in detail in Chichester (1988), Fishel and others (1992), and Koerkle and others (1996). Summaries of the methods used and modifications of them are presented in the following section.

\section{Sampling Network}

The sampling network consisted of four surface-water streamflow and water-quality sites, three benthic-macroinvertebrate sampling sites, four soil-nutrient sampling sites, and one precipitation-gaging site (fig. 1). Two of the surface-water sites were continuous-record discharge and two were partial record (base-flow discharge at time of water-quality sampling) (table 2). Surface-water sites are identified by USGS station numbers and codes. The codes are used to refer to the sites in this text. Site NM1 drained a noncarbonate, mostly forested area. Sites NM5 and NC1 drained the Nutrient-Management and 
Nonnutrient-Management Subbasins, respectively. Site SW1 drained the entire Small Watershed. Benthic macroinvertebrates were sampled at the following locations: $300 \mathrm{ft}$ upstream of site NM1, $200 \mathrm{ft}$ upstream of site NM5, and $100 \mathrm{ft}$ downstream of site NC1. Soil-nutrient sampling sites were in the Nutrient-

Management Subbasin (fig. 1). All sampling sites were established during the 1984-89 RCWP study.

Table 2. Small Watershed study area surface-water data-collection stations

$\left[\mathrm{mi}^{2}\right.$, square mile; C, continuous record; P, partial record; ${ }^{\circ}$, degree; ', minute; ", second]

\begin{tabular}{|c|c|c|c|c|c|c|c|}
\hline $\begin{array}{l}\text { U.S. Geological } \\
\text { Survey } \\
\text { identification } \\
\text { number }\end{array}$ & $\begin{array}{l}\text { Site } \\
\text { code }\end{array}$ & Station name & $\begin{array}{l}\text { Drainage } \\
\text { basin }\end{array}$ & $\begin{array}{l}\text { Station } \\
\text { type }\end{array}$ & $\begin{array}{c}\text { Drainage } \\
\text { area } \\
\left(\mathrm{mi}^{2}\right)\end{array}$ & Latitude & Longitude \\
\hline 015760831 & NM1 & $\begin{array}{l}\text { Little Conestoga Creek, }{ }^{1} \text { site } 1, \\
\text { near Morgantown, Pa. }\end{array}$ & $\begin{array}{l}\text { Nutrient } \\
\text { Management }\end{array}$ & $P$ & 0.34 & $40^{\circ} 09^{\prime} 22^{\prime \prime}$ & $75^{\circ} 55^{\prime} 14^{\prime \prime}$ \\
\hline 0157608335 & NM5 & $\begin{array}{l}\text { Little Conestoga Creek, site 3A, } \\
\text { near Morgantown, Pa. }\end{array}$ & $\begin{array}{l}\text { Nutrient } \\
\text { Management }\end{array}$ & C & 1.42 & $40^{\circ} 08^{\prime} 47^{\prime \prime}$ & $75^{\circ} 55^{\prime} 37^{\prime \prime}$ \\
\hline 015760839 & NC1 & $\begin{array}{l}\text { Unnamed tributary to Little Conestoga } \\
\text { Creek, site 9, at Churchtown, Pa. }\end{array}$ & $\begin{array}{l}\text { Nonnutrient } \\
\text { Management }\end{array}$ & $P$ & 1.43 & $40^{\circ} 08^{\prime} 20^{\prime \prime}$ & $75^{\circ} 58^{\prime} 14^{\prime \prime}$ \\
\hline 01576085 & SW1 & $\begin{array}{l}\text { Little Conestoga Creek } \\
\text { near Churchtown, Pa. }\end{array}$ & $\begin{array}{l}\text { Small } \\
\text { Watershed }\end{array}$ & C & 5.82 & $40^{\circ} 08^{\prime} 41^{\prime \prime}$ & $75^{\circ} 59^{\prime} 20^{\prime \prime}$ \\
\hline
\end{tabular}

${ }^{1}$ The original source of reference for the Little Conestoga Creek referred to in this report comes from the U.S. Geological Survey Morgantown Quadrangle of 1939. The 1975 photorevision of the Morgantown Quadrangle designates the stream as an unnamed tributary to the Conestoga River. The Little Conestoga Creek referred to in this report should not be confused with the Little Conestoga Creek that discharges to the Conestoga River near Safe Harbor and is found on the Conestoga Quadrangle.

\section{Data Collection}

A summary of the data-collection schedule is listed in table 3. Data collection was modified from the RCWP studies (Koerkle and others, 1996) primarily by increasing the number of farms providing agricultural-activity data from those located just in the Nutrient-Management Subbasin to all those in the entire Small Watershed willing to provide data. Streamflow and water-quality data were not collected at site NM1 from October 1989 to September 1990. Initially discontinued for the 1989-91 study extension, site NM1 was reactivated as a stable land-use site to be used as a reference for climatic variability. Base-flow samples were collected during periods of stable stage and no earlier than 3 days after a stormflow event. Stormflow samples were collected when precipitation driven rises in stream stage exceeded the average stage prior to precipitation by $0.10 \mathrm{ft}$ or more at site NM5 and by $0.25 \mathrm{ft}$ or more at site SW1.

Table 3. Data-collection schedule for the Small Watershed study from October 1989 through September 1991

\begin{tabular}{lll}
\hline \multicolumn{1}{c}{ Location } & \multicolumn{1}{c}{ Data type } & Frequency \\
\hline Continuous-record stations (NM5, SW1) & Nutrients and suspended sediment & Monthly base flow and major storms \\
Partial-record stations (NM1, NC1) & Nutrients and suspended sediment & Monthly base flow \\
Rowcrop fields (4 sites) & Nutrients in soil column & Spring and fall \\
Precipitation gage (1 site) & Precipitation intensity and total & 5 -minute intervals \\
Individual farms (41 sites) & accumulation & Spring and fall \\
\hline
\end{tabular}


Water-quality samples were analyzed for 2 physical characteristics and for 11 chemical (nutrients and suspended sediment) constituents (table 4). Samples from base-flow discharge were analyzed in the laboratory for concentrations of total and dissolved nutrients and suspended sediment. Temperature and specific conductivity were measured at the sampling site. Discrete samples from selected storms were analyzed in the laboratory for concentrations of total nutrients and suspended sediment. Physical characteristics of stormflow samples were not measured. An average of six nutrient and six suspendedsediment samples were collected for each sampled storm. Water-quality data collected during the study period are published in USGS Water-Data Reports PA-90-2 (Loper and others, 1991) and PA-91-2 (Durlin and Schaffstall, 1992).

Table 4. Physical characteristics and chemical constituents for which surface-water samples in the Small Watershed were analyzed

$\left[{ }^{\circ} \mathrm{C}\right.$, degree Celsius; $\mu \mathrm{S} / \mathrm{cm}$, microsiemens per centimeter at 25 degrees Celsius; mg/L, milligrams per liter]

\begin{tabular}{|c|c|}
\hline $\begin{array}{l}\text { Characteristic or } \\
\text { constituent }\end{array}$ & $\begin{array}{l}\text { Laboratory minimum } \\
\text { reporting levels }{ }^{1}\end{array}$ \\
\hline Temperature (field) & Measured to nearest $0.5^{\circ} \mathrm{C}$ \\
\hline Specific conductance (field) & 1 to $10 \mu \mathrm{S} / \mathrm{cm}$ dependent on value \\
\hline Suspended sediment & $1 \mathrm{mg} / \mathrm{L}$ \\
\hline \multicolumn{2}{|l|}{ Total and dissolved nutrients: } \\
\hline Ammonium $^{2}$ plus organic nitrogen & $.2 \mathrm{mg} / \mathrm{L}$ \\
\hline Ammonium $^{2}$ & $.02 \mathrm{mg} / \mathrm{L}$ \\
\hline Nitrate plus nitrite & $.04 \mathrm{mg} / \mathrm{L}$ \\
\hline Nitrite & $.01 \mathrm{mg} / \mathrm{L}$ \\
\hline Phosphorus & $.02 \mathrm{mg} / \mathrm{L}$ \\
\hline
\end{tabular}

Benthic-macroinvertebrate samples were collected by use of procedures described by the Pennsylvania Department of Environmental Resources, Bureau of Water Quality Management (1988). Samples were collected with a $1-\mathrm{ft}^{2}$ Surber ${ }^{2}$ sampler and a $3-\mathrm{ft}^{2}$ kick screen. The kick-screen sampling interval was 60 seconds. All collections were made in triplicate and composited. Identifications were assigned by Andrew G. Reif, USGS, Water Resources Division, Malvern, Pa. Identifications were attempted to the lowest practical level (usually genus), and all counts refer to a three-sample composite prepared at each site.

Agricultural-activity data were tabulated from records kept by farmers in the Small Watershed. Agricultural-activity data were collected from 41 of 51 farms in the Small Watershed. Of the 10 farms not supplying agricultural-activity data, 2 were in the Nutrient-Management Subbasin and 4 were in the Nonnutrient-Management Subbasin. Data for one farm in the Nutrient-Management Subbasin were estimated from drive-by inspection.

\footnotetext{
${ }^{2}$ Any use of trade, product, or firm names is for descriptive purposes only and does not imply endorsement by the U.S. Government.
} 
Soil-nutrient samples were collected twice a year: once before spring planting and application of commercial fertilizer and again after fall harvest. Sample soil cores were collected to depths of $4 \mathrm{ft}$ and split into three sections. Concentrations of soluble orthophosphorus, nitrate, ammonium, and ammonium plus organic nitrogen were determined for each section. A limited number of soil-nutrient samples were collected from depths between 4 and $8 \mathrm{ft}$.

\section{Data Analysis}

Parametric and nonparametric statistical techniques were applied to make statistical inferences concerning water-quality and streamflow trends and to examine the relation between water quality and nutrient inputs in the Small Watershed. Inferences concerning base-flow water quality and the relation between water quality and nutrient management were made with the aid of boxplots, time-series plots, step-trend tests, and paired-basin analyses. Step-trend tests were performed by use of a seasonally grouped Mann-Whitney rank-sum test, a nonparametric procedure comparing two independent sample populations. This test groups samples by season to remove seasonal variation in the data. Season divisions used were months. Changes in the relation between concurrent concentrations in base-flow samples from the Nutrient-Management and Nonnutrient-Management Subbasins were evaluated by use of analysis of covariance (Spooner and others, 1985). Step trends in stormflow water-quality data were evaluated by use of the Mann-Whitney rank-sum test. Statistical tests were evaluated at a confidence level of 95 percent ( $p$-values $\leq 0.05)$ unless otherwise stated.

Flow adjustment of constituents was applied where applicable to remove flow-dependent variation in constituent concentrations. Reduced variance improves the power of statistical tests. Flow adjustment was achieved by subtracting LOWESS (Locally weighted scatterplot smooth) values fitted to the relation between streamflow and concentration from the observed concentrations. The LOWESS smoothing procedure generates a curve by fitting numerous weighted least squares equations to the data. The number of curves fitted is established by the smoothing factor. A factor of 0.6 was used for flow adjustments.

Benthic-macroinvertebrate data were summarized by EPT Index values. The EPT Index represents taxa richness within the orders that are considered "pollution intolerant" (Klemm and others, 1990). EPT Index values were determined for each site from macroinvertebrate identifications and counts.

Loads were calculated by summing base-flow and stormflow loads. Base-flow loads were calculated by multiplying daily base-flow concentrations by base-flow discharge as determined by use of the local minimum hydrograph-separation procedure (Pettyjohn and Henning, 1979). Unknown daily concentrations were estimated by use of linear interpolation between measured monthly concentrations. Stormflow loads were calculated by use of the subdivided-interval method (Porterfield, 1972).

\section{Quality Assurance}

A quality-assurance (QA) plan for nutrient water-quality analyses was maintained with the PaDEP, Bureau of Laboratories for the purpose of monitoring the analytical performance of the PaDEP laboratory. Analytical performance of the laboratory was evaluated using QA data from this study, the Conestoga Headwaters RCWP water-quality studies, and from the USGS, National Water Quality Laboratory, Standard Reference Water Sample Program. Protocol for the QA plan called for the routine submission of QA samples. Three types of QA samples were used: preservation blank, reference, and field-split duplicate samples. Preservation blanks consisting of distilled water were used to evaluate the laboratory's baseline analytical capabilities at near detection-limit levels. Reference samples prepared from USEPA Quality Control samples were used for determining analytical accuracy. Field-split duplicate samples were used in the evaluation of analytical precision. Quality-assurance data were monitored during the project and corrective steps were taken if the data indicated problems. 


\section{HYDROLOGIC SETTING AND CONDITIONS}

\section{Hydrologic Setting}

The Little Conestoga Creek and its tributaries originate in the northern half of the basin but are primarily situated in and gain most of their flow in the valley underlain by carbonate bedrock in the southern half of the basin. Stream base flow, whose source is ground water, contributed about 60 percent of total annual streamflow from 1984 through 1991.

Gerhart and Lazorchick (1984) describe the ground-water hydrology of the area as having an unconfined aquifer with predominantly localized ground-water flow paths. Ground-water recharge following localized flow paths discharges to streams within the local drainage basin. However, a question exists whether a portion of ground-water recharge in the Small Watershed is being diverted to the Conestoga River Basin. Along the eastern end of the Small Watershed, the Conestoga River, which is approximately parallel to and within $0.5 \mathrm{mi}$ of the topographic divide between the basins, is 50 to $70 \mathrm{ft}$ lower than the Little Conestoga Creek. Given these conditions, some portion of ground-water recharge in the Small Watershed may discharge to the Conestoga River rather than to the Little Conestoga Creek. If the ground-water diversion is occurring, the effect of nutrient inputs and changes in those inputs in areas where ground-water recharge does not flow to the Little Conestoga Creek would be reduced.

\section{Precipitation}

Long-term average annual precipitation for the Small Watershed is about $42 \mathrm{in.} \mathrm{Annual}$ precipitation recorded for 1990 and 1991 at the Small Watershed was $37.8 \mathrm{in.}$ and $37.1 \mathrm{in}$., respectively. These totals represent an average departure from the long-term average of -10 percent. By comparison, departures from the long-term average in the 2-year period prior to implementation of nutrient management (1984-86) were -14 percent and -6 percent (Koerkle and others, 1996). The similarity in annual precipitation between the pre-nutrient management and study periods minimizes the potential for precipitation-dependent changes in water quality to mask changes caused by nutrient management.

\section{Streamflow}

Daily mean streamflows for site SW1 (01576085) and site NM5 (0157608335) have been published in USGS Water-Data Reports PA-90-2 (Loper and others, 1991) and PA-91-2 (Durlin and Schaffstall, 1992).

Daily mean streamflows for the 1990 and 1991 water years were below average for the period of record. A water year is the 12-month period October 1 through September 30 and is designated by the calendar year in which it ends. Monthly mean streamflows (table 5) (fig. 2) at site SW1 were below the period-of-record average 67 percent of the time in 1990 and 75 percent of the time in 1991. The cumulative departure of monthly mean streamflows from the period-of-record average at site SW1 (fig. 3) shows decreasing streamflows for most of the study period. Similar behavior in streamflow was recorded in 1984-86 (prenutrient management period) and is in contrast to the increasing, cumulative departure during 1986-89. Sustained increases or decreases in the cumulative departures from average are indicative of a trend in streamflow. As with precipitation, similarity in streamflow between periods minimizes flow-dependent water-quality conditions from masking the effects of nutrient management on water quality.

The presence of a trend in streamflow can interfere with interpretation of trend test results for constituent concentrations that have been flow adjusted. Base-flow data from sites SW1 and NM5 were tested for trend across the pre-nutrient management period and the study period. A Mann-Whitney ranksum test of monthly mean base flows showed no significant step-trend at either site SW1 (p-value = 0.91) or site NM5 ( $p$-value $=0.18$ ). Stormflow data were not tested for trend over time.

Stormflows measured at site SW1 were smaller during the study period than during the pre-nutrient management period, and, as a result, decreased constituent loads at site SW1 could be expected for the study period even if constituent concentrations had not decreased because of nutrient management. Median and maximum mean stormflows at site SW1 were about one-half those reported by Koerkle and 
Table 5. Monthly, annual, and period-of-record mean streamflow and mean base flow, in cubic feet per second, at sites SW1 and NM5 in the Small Watershed

[--, no data]

\begin{tabular}{|c|c|c|c|c|}
\hline \multirow{2}{*}{ Month } & \multicolumn{2}{|c|}{$1989-1990$} & \multicolumn{2}{|c|}{$1990-1991$} \\
\hline & Streamflow & Base flow & Streamflow & Base flow \\
\hline \multicolumn{5}{|c|}{ Site SW1 } \\
\hline October & 6.54 & 2.73 & 3.09 & 1.95 \\
\hline November & 4.40 & 3.56 & 5.11 & 2.97 \\
\hline December & 2.69 & 2.23 & 9.21 & 5.21 \\
\hline January & 12.10 & 5.20 & 9.78 & 7.84 \\
\hline February & 8.77 & 7.64 & 5.55 & 5.17 \\
\hline March & 4.91 & 4.60 & 7.44 & 6.09 \\
\hline April & 6.67 & 5.46 & 6.30 & 5.60 \\
\hline May & 7.74 & 3.90 & 4.09 & 3.74 \\
\hline June & 7.57 & 4.13 & 2.31 & 2.12 \\
\hline July & 2.20 & 1.90 & 2.11 & 1.24 \\
\hline August & 5.03 & 2.90 & 2.64 & .93 \\
\hline September & 3.11 & 2.39 & 1.41 & .52 \\
\hline Annual mean & 5.96 & 3.89 & 4.93 & 3.61 \\
\hline Period-of-record mean & 7.03 & -- & 7.03 & -- \\
\hline \multicolumn{5}{|c|}{$\underline{\text { Site NM5 }}$} \\
\hline October & 1.06 & .37 & .52 & .34 \\
\hline November & .65 & .57 & .70 & .41 \\
\hline December & .28 & .22 & 1.37 & .87 \\
\hline January & 2.35 & .86 & 1.82 & 1.63 \\
\hline February & 1.68 & 1.54 & 1.18 & 1.14 \\
\hline March & .81 & .78 & 1.26 & 1.10 \\
\hline April & 1.06 & .87 & 1.28 & 1.16 \\
\hline May & 1.49 & .86 & .90 & .82 \\
\hline June & 1.47 & 1.18 & .63 & .60 \\
\hline July & .72 & .66 & .66 & .42 \\
\hline August & 1.02 & .63 & .47 & .23 \\
\hline September & .52 & .39 & .36 & .15 \\
\hline Annual mean & 1.09 & .74 & .93 & .74 \\
\hline Period-of-record mean & 1.13 & -- & 1.13 & -- \\
\hline
\end{tabular}




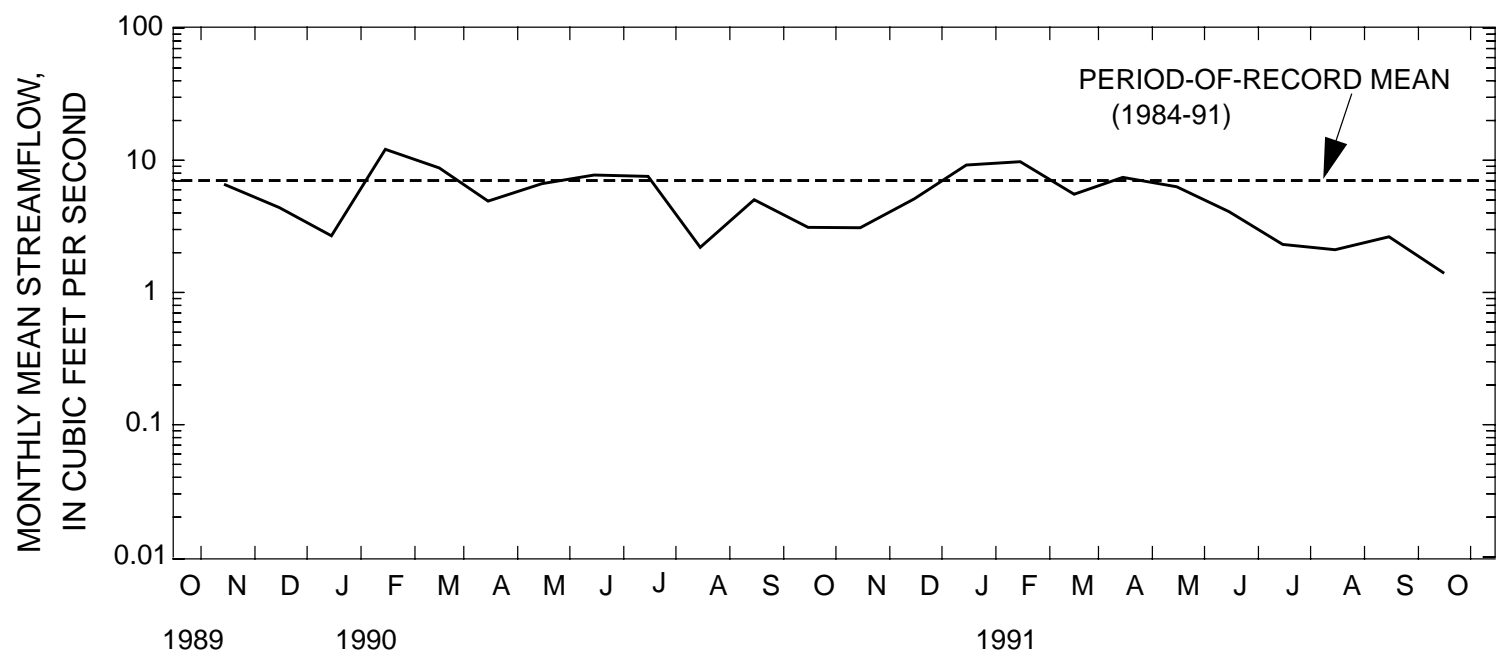

Figure 2. Monthly mean streamflow at site SW1 in the Small Watershed.

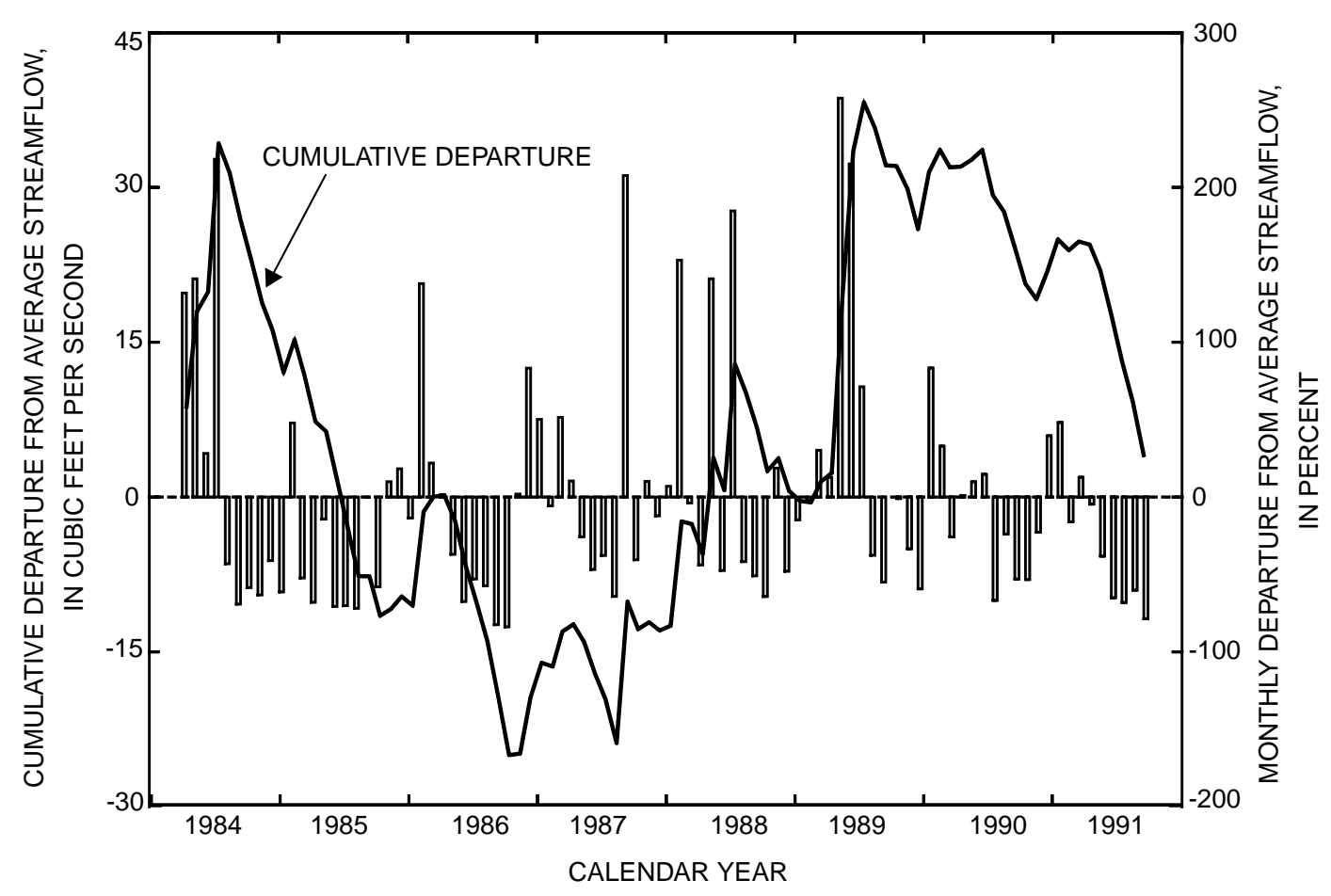

Figure 3. Monthly departure from average streamflow, in percent, and cumulative departure from average streamflow, in cubic feet per second, at site SW1 in the Small Watershed. 
others (1996) for the pre-nutrient management period. The median value for mean stormflow at site NM5 was nearly identical to the median value for the 1984-86 (pre-nutrient management) period, although the range of stormflows was greater during the pre-nutrient management period. The disparity between sites SW1 and NM5 when comparing changes in mean stormflow can be explained at least partly by the differences in drainage areas and the hit-or-miss nature of localized thunderstorms that accounted for a large part of the recorded stormflow events.

\section{NUTRIENT MANAGEMENT, SOURCES, AND SINKS}

\section{Nutrient Management}

The number of farms implementing nutrient management increased during the 2-year study extension. As of September 1989, 21 farms, covering about 55 percent of the total agricultural acreage in the Small Watershed, had received nutrient-management plans. In 1989, local cooperative extension service personnel revisited the watershed trying to increase the number of nutrient-management plans. Between September 1989 and December 1991, 11 new plans were prepared for farms in the watershed (fig. 4). These new plans increased the acreage under nutrient management by 25 percent in the Small Watershed overall, by 0 percent in the Nutrient-Management Subbasin, and by 25 percent in the Nonnutrient-Management Subbasin (table 6). An increase in nutrient management in the NonnutrientManagement Subbasin was not desirable for the paired-subbasins experiment as it diminished the value of the Nonnutrient-Management Subbasin as a control.

\section{Manure Production}

Manure production estimated from animal-inventory data was used to check the relative accuracy of application and export data. Manure production was estimated for the entire Small Watershed, excluding 14 farms, and for the Nutrient-Management Subbasin, excluding 2 farms. Manure production was not estimated for the Nonnutrient-Management Subbasin because of the limited number of farms supplying data.

Total manure production in the Small Watershed was 39,500 ton per year for 1989-91 from an animal inventory that averaged 3,270 AU (animal units). One AU represents 1,000 lb of animal weight regardless of type. Dairy cattle accounted for 57 percent, beef 20 percent, swine 11 percent, poultry 7 percent, and horses and mules 5 percent by weight of the total animal population. The average animal density in the Small Watershed when distributed over 1,950 acres of cropland and pasture land for which data was available was 1.7 AU per acre. No data were available to determine changes in animal populations and manure production since 1984-86. The manure produced contained 450,000 lb of nitrogen and 101,600 lb of phosphorus. Manure produced at farms not wholly within the watershed was adjusted by proportioning by the percentage of farm acreage within the Small Watershed. Adjusted manure production yielded about $408,800 \mathrm{lb}$ of nitrogen and 92,500 lb of phosphorus available for input to the Small Watershed. Nutrientmanagement plans showed that about 70 percent of the available manure was collected for spreading or export.

Manure production in the Nutrient-Management Subbasin was 11,980 ton per year from an average $950 \mathrm{AU}$, of which 53 percent was dairy, 18 percent swine, 15 percent beef, 11 percent poultry, and 3 percent horses and mules. The average animal density for the 14 farms reporting in the Nutrient-Management Subbasin was $1.5 \mathrm{AU}$ per acre distributed over 635 acres of cropland and pasture land. Manure from the Nutrient-Management Subbasin contained 148,400 lb of nitrogen and 34,900 lb of phosphorus. When adjusted for farms only partially within the subbasin, manure nutrients available for input to the subbasin totaled $126,800 \mathrm{lb}$ of nitrogen and 30,200 lb of phosphorus. Nutrient-management plans indicated that 75 percent of the total manure production would be collected for spreading or export. 


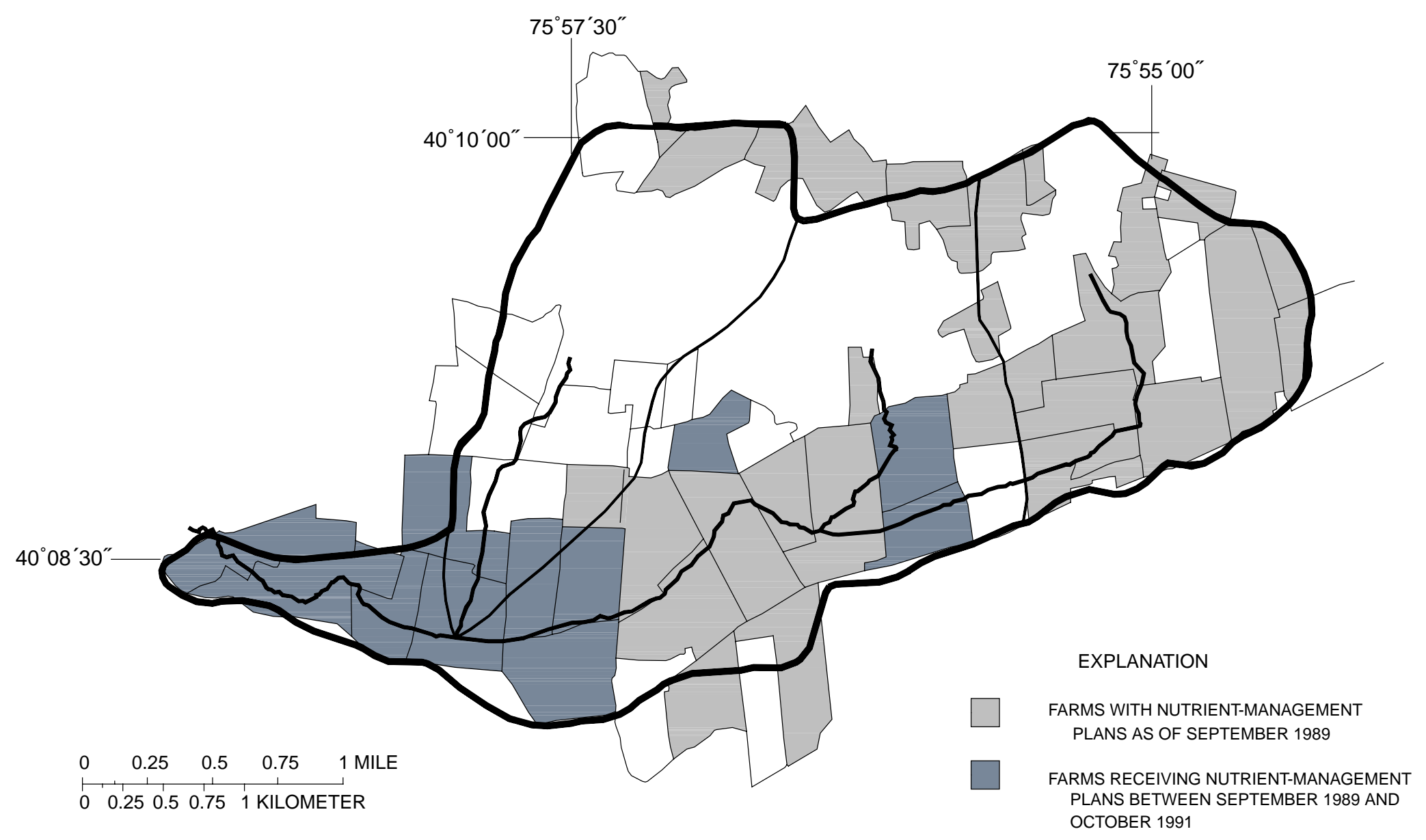

Figure 4. Distribution of nutrient-management plans in the Small Watershed. 
Table 6. Percentage of agricultural land in the Small Watershed included under nutrient-management plans, September 1989 to September 1991

\begin{tabular}{cccc}
\hline \multirow{2}{*}{ Year } & Small & \multicolumn{2}{c}{ Subbasin } \\
\cline { 3 - 4 } & Watershed & $\begin{array}{c}\text { Nutrient } \\
\text { Management }\end{array}$ & $\begin{array}{c}\text { Nonnutrient } \\
\text { Management }\end{array}$ \\
\hline 1989 & 55 & 90 & 15 \\
1990 & 80 & 90 & 40 \\
1991 & 80 & 90 & 40 \\
\hline
\end{tabular}

The average animal population in the Nutrient-Management Subbasin was about 15 percent less than the average reported by Fishel and others (1992) for 1984-86 and 9 percent less than the average population reported by Koerkle and others (1996) for 1986-89, the first 3.5 years of nutrient management. Estimated annual manure nutrient production was about 28 percent lower than reported for 1984-86 (the pre-nutrient management period) by Fishel and others (1992).

Estimates of the amount of nitrogen deposited in pasture were between 25 and 30 percent of the total nitrogen production and were determined by multiplying total nitrogen production by the percentage of time animals were not in confinement. Time of animal confinement was listed in the nutrient-management plans. Because manure deposited in pasture was not collected, it was not listed in nutrient-management plans as a source of nutrients available for cropland application. For water-quality purposes, however, pasture manure was considered a substantial nutrient input. In addition, because most pastures are next to the stream channel, manure deposited there may have had a greater effect on water quality than nutrient applications to fields further from the stream, thus partially masking the effects of nutrient management.

\section{Nutrient Application and Manure Export}

Total reported applications of nitrogen and phosphorus for the study period are listed in table 7 for the Small Watershed and the Nutrient-Management Subbasin. Application data for the NonnutrientManagement Subbasin are not presented because of the limited number of farms reporting. Manure was the primary nutrient source in the Small Watershed and accounted for about 83 percent of the nitrogen and 67 percent of the phosphorus applied.

Table 7. Reported nutrient applications to cropland in the Small Watershed and Nutrient-Management Subbasin, in pounds, for October 1989 through September 1991

[--, no data]

\begin{tabular}{|c|c|c|c|c|c|c|}
\hline & \multicolumn{3}{|c|}{ Nitrogen } & \multicolumn{3}{|c|}{ Phosphorus } \\
\hline & Manure & $\begin{array}{l}\text { Commercial } \\
\text { fertilizer }\end{array}$ & Total & Manure & $\begin{array}{l}\text { Commercial } \\
\text { fertilizer }\end{array}$ & Total \\
\hline Small Watershed $^{1}$ & 764,000 & 159,800 & 923,800 & 187,200 & 91,700 & 278,900 \\
\hline Nutrient-Management Subbasin ${ }^{2,3}$ & 195,600 & 27,900 & 223,500 & 34,500 & 13,500 & 48,000 \\
\hline $\begin{array}{l}\text { Annual average, } \\
\text { Nutrient-Management Subbasin }\end{array}$ & 97,800 & 13,950 & 111,800 & 17,250 & 6,750 & 24,000 \\
\hline
\end{tabular}

${ }^{1}$ Values for Small Watershed exclude 10 farms.

${ }^{2}$ Values for Nutrient-Management Subbasin exclude two farms.

${ }^{3}$ Nonnutrient-Management Subbasin information not presented because of limited data. 
Annual average nitrogen and phosphorus application rates for the Small Watershed and NutrientManagement Subbasin are listed in table 8. These rates were determined only for crop and pasture land for which data were available. A customary fertilizer recommendation for 125 bushels per acre of grain corn is $130 \mathrm{lb}$ per acre of nitrogen as nitrogen and 0 to $130 \mathrm{lb}$ per acre of phosphorus as $\mathrm{P}_{2} \mathrm{O}_{5}$ depending on soil test results (Chambers, 1991). Reported application rates of nitrogen were about 35 percent greater and phosphorus application rates were about 40 percent greater in the Small Watershed overall than in the Nutrient-Management Subbasin. Agricultural-activity data showed that some of the difference was caused by redistribution of the manure produced in the Nutrient-Management Subbasin to other areas of the Small Watershed. In addition, animal density in the Small Watershed was 13 percent greater than in the Nutrient-Management Subbasin.

Table 8. Average annual nitrogen and phosphorus application rates ${ }^{1}$, in pounds per acre of crop and pasture land, in the Small Watershed, Nutrient-Management Subbasin, and Nonnutrient-Management Subbasin for October 1989 through September 1991

\begin{tabular}{lccc}
\hline & Acres & Nitrogen & Phosphorus \\
\hline Small Watershed & 1,950 & 235 & 70 \\
Nutrient-Management Subbasin & 635 & 175 & 40 \\
Nonnutrient-Management Subbasin & 2355 & 145 & 45 \\
\hline
\end{tabular}

${ }^{1}$ Rate calculations exclude 10 farms in the Small Watershed, 3 farms in the Nutrient-Management Subbasin, and 4 farms in the Nonnutrient-Management Subbasin.

${ }^{2}$ Estimated on the basis of 90 percent of agricultural land use being cropland or pasture land.

Reported nitrogen applications in the Nutrient-Management Subbasin decreased slightly from 198486 (pre-nutrient management) to 1989-91 (fig. 5). Nitrogen applications averaged about 7 percent less than 1984-86 applications. (Koerkle and others [1996] reported a substantially larger 30-percent average decrease in nitrogen applications for 1986-89 for the first 3 years of nutrient management.) The 7-percent reduction in total nitrogen applications consisted of a 3-percent increase in manure nitrogen applications and a 44-percent reduction in commercial fertilizer use. Phosphorus applications were 25 percent below 1984-86 applications reported by Fishel and others (1992). Phosphorus applications from manure decreased 30 percent, and phosphorus applications from commercial fertilizer increased 2 percent.

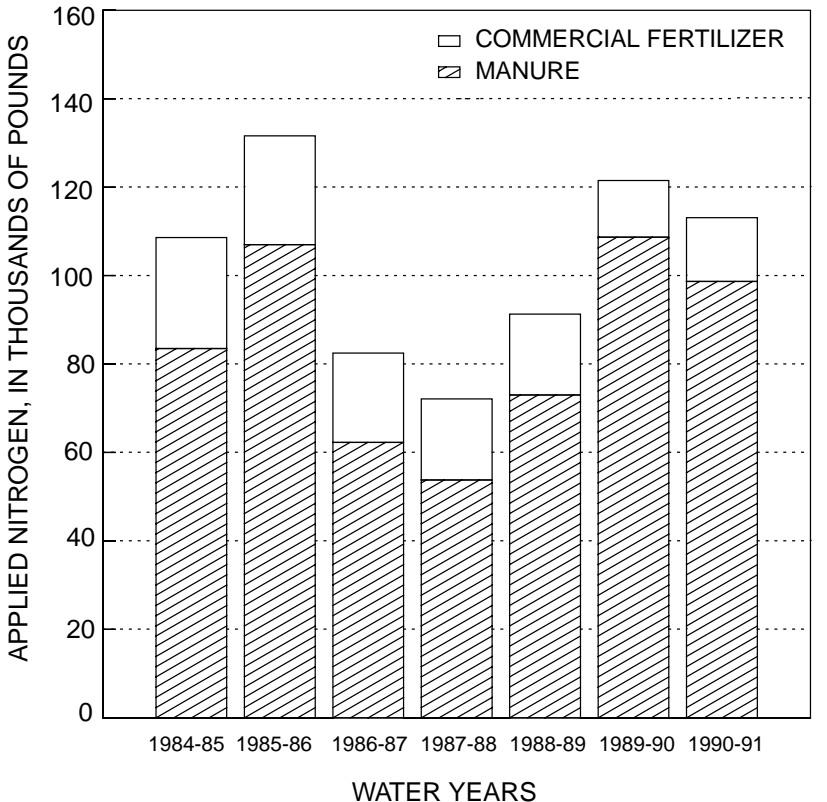

Figure 5. Annual applications of nitrogen to cropland in the Nutrient-Management Subbasin of the Small Watershed. 
Reported exports of manure were greater in 1989-91 than during 1984-86 (pre-nutrient management) and 1986-89. Annual exports of nitrogen in manure from the Nutrient-Management Subbasin (table 9) in 1990 and 1991 were about 30 percent and 55 percent greater, respectively, than those reported for 1985-86, the year of greatest reported exports. However, Koerkle and others (1996) cautioned that manure exports were probably underreported in the latter part of the 1986-89 period.

Table 9. Average annual exports of nitrogen and phosphorus from the Small Watershed and Nutrient-Management Subbasin for October 1989 through September 1991

[All values are in pounds]

\begin{tabular}{lrc}
\hline \multicolumn{1}{c}{ Location $^{1}$} & Nitrogen & Phosphorus \\
\hline Small Watershed & 24,000 & 6,720 \\
Nutrient-Management Subbasin & 13,600 & 4,240 \\
\hline \multicolumn{1}{c}{ 1 }
\end{tabular}

${ }^{1}$ No data available for the Nonnutrient-Management Subbasin.

Total reported applications plus exports were greater than expected. The difference between nitrogen content of applications and exports of manure and estimated nitrogen production was about 1 percent for the Small Watershed. However, nutrient-management plans indicated that about 25 percent of the manure produced was not collected and could neither be applied nor exported. A substantial portion of this discrepancy is likely caused by the difficulty of accurately measuring and reporting nutrient applications. In the Nutrient-Management Subbasin, nitrogen in applications and exports was 12 percent less than the expected production from reported animal populations.

From reported nitrogen-application data, it appeared unlikely that significant improvements in water quality would be realized. Reported 1989-91 applications of nitrogen in the Nutrient-Management Subbasin were within 12 percent or less of 1984-86 (pre-nutrient management) applications. In addition, nitrogen-application rates in the Small Watershed overall were larger than rates in the NutrientManagement Subbasin (table 8). There was little correlation between the high percentage of nutrientmanagement plans prepared and a substantial reduction in reported nitrogen applications in the NutrientManagement Subbasin. Nevertheless, the considerable uncertainty in the manure-nitrogen data and the reductions in commercial fertilizer use leave open the possibility that real reductions in nitrogen inputs have occurred.

\section{Soil Nutrients}

Soil-nutrient samples were collected in the spring and fall of 1990 and 1991. Two-inch diameter cores to a 48-in. depth were extracted at all sites. Cores from deeper than $48 \mathrm{in}$. were collected at least once at three of the four sites. Nitrate and ammonia were distributed variably throughout the top $48 \mathrm{in}$. of soil and also were detected in large amounts from 48 to 96 in. in depth (tables 10 and 11). Ammonia plus organic nitrogen was distributed throughout the top $48 \mathrm{in.} \mathrm{of} \mathrm{soil} \mathrm{but} \mathrm{tended} \mathrm{to} \mathrm{decrease} \mathrm{with} \mathrm{depth.}$ Substantial amounts of ammonia plus organic nitrogen also were detected in cores from 48 to 96 in. in depth. Orthophosphorus was present mostly in the top 8 in. of soil (table 10).

With two exceptions, no consistent increases or decreases in soil nutrients were detected over the period April 1984 through October 1991. Nitrate-nitrogen and orthophosphorus data for the top 48 in. of the soil column are shown in figures 6 and 7. At farm F, the median amount of nitrate nitrogen was $178 \mathrm{lb} /$ acre in 1984-86 and $72.5 \mathrm{lb} /$ acre in 1989-91. At farm H, the median amount of orthophosphorus was $18.2 \mathrm{lb} /$ acre in 1984-86 and 4.2 lb/acre in 1989-91. Because ammonia and ammonia-plus-organic-nitrogen data were collected only in 1989-91, a comparison with amounts existing prior to nutrient management could not be made. 
Table 10. Amounts of soluble nitrate nitrogen and orthophosphorus in soil samples from four farms in the Nutrient-Management Subbasin, in pounds per acre per depth

$[--$, no data]

\begin{tabular}{|c|c|c|c|c|c|c|c|c|c|c|c|c|c|c|c|c|c|}
\hline \multirow[b]{2}{*}{$\begin{array}{c}\text { Depth } \\
\text { (inches) }\end{array}$} & \multirow[b]{2}{*}{ Constituent } & \multicolumn{4}{|c|}{ Farm D } & \multicolumn{4}{|c|}{ Farm F } & \multicolumn{4}{|c|}{ Farm H } & \multicolumn{4}{|c|}{ Farm M } \\
\hline & & $\begin{array}{c}\text { Spring } \\
1990\end{array}$ & $\begin{array}{c}\text { Fall } \\
1990\end{array}$ & $\begin{array}{c}\text { Spring } \\
1991\end{array}$ & $\begin{array}{c}\text { Fall } \\
1991\end{array}$ & $\begin{array}{c}\text { Sprin } \\
\text { g } \\
1990\end{array}$ & $\begin{array}{c}\text { Fall } \\
1990\end{array}$ & $\begin{array}{c}\text { Spring } \\
1991\end{array}$ & $\begin{array}{c}\text { Fall } \\
1991\end{array}$ & $\begin{array}{c}\text { Spring } \\
1990\end{array}$ & $\begin{array}{c}\text { Fall } \\
1990\end{array}$ & $\begin{array}{c}\text { Spring } \\
1991\end{array}$ & $\begin{array}{c}\text { Fall } \\
1991\end{array}$ & $\begin{array}{c}\text { Spring } \\
1990\end{array}$ & $\begin{array}{c}\text { Fall } \\
1990\end{array}$ & $\begin{array}{c}\text { Spring } \\
1991\end{array}$ & $\begin{array}{c}\text { Fall } \\
1991\end{array}$ \\
\hline \multirow[t]{2}{*}{$0-8$} & Nitrate & 49.5 & 29.8 & 56.5 & 21.9 & 20.2 & 38.7 & 11.3 & 55.0 & 14.4 & 59.8 & 11.0 & 17.1 & 176.8 & 86.2 & 20.9 & 25.2 \\
\hline & Orthophosphorus & 16.4 & 10.4 & 21.4 & 2.8 & 7.6 & 11.5 & 7.2 & 4.0 & 2.7 & 5.3 & 3.9 & 3.3 & 10.3 & 11.1 & 16.9 & 7.2 \\
\hline \multirow[t]{2}{*}{$8-24$} & Nitrate & 37.0 & 31.7 & 64.9 & 23.5 & 11.5 & 23.5 & 22.1 & 63.4 & 46.6 & 78.8 & 12.5 & 8.2 & 83.1 & 67.8 & 21.1 & 43.7 \\
\hline & Orthophosphorus & 6.6 & 1.0 & .3 & .3 & .2 & .7 & 1.5 & .2 & .2 & .2 & .2 & .2 & .2 & .5 & .2 & .2 \\
\hline \multirow[t]{2}{*}{$24-36$} & Nitrate & 13.3 & 30.3 & 36.4 & 11.5 & 5.8 & 10.8 & 14.4 & 7.9 & 43.2 & 31.4 & 9.0 & 6.8 & 26.3 & 42.9 & 15.5 & 22.7 \\
\hline & Orthophosphorus & .2 & .5 & .2 & .2 & .2 & .3 & .2 & .2 & .2 & .2 & .2 & .2 & .2 & .4 & .2 & .2 \\
\hline \multirow[t]{2}{*}{$36-48$} & Nitrate & 11.5 & 20.2 & 34.6 & 7.6 & 5.4 & 10.4 & 13.7 & 10.8 & 54.8 & 13.3 & 12.6 & 32.1 & 28.5 & 22.7 & 13.3 & 13.3 \\
\hline & Orthophosphorus & .2 & .3 & .2 & .2 & .2 & .2 & .2 & .2 & .2 & .2 & .2 & .2 & .2 & .3 & .2 & .2 \\
\hline \multirow[t]{2}{*}{${ }^{1} 0-48$} & Nitrate & 111 & 112 & 192 & 64.5 & 42.9 & 83.5 & 61.5 & 137 & 159 & 183 & 45.2 & 64.2 & 315 & 220 & 70.8 & 105 \\
\hline & Orthophosphorus & 23.4 & 12.2 & 22.1 & 3.5 & 8.2 & 12.5 & 9.1 & 4.6 & 3.3 & 5.9 & 4.5 & 3.9 & 10.9 & 12.3 & 17.5 & 7.8 \\
\hline \multirow[t]{2}{*}{$48-72$} & Nitrate & 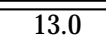 & 34.6 & 86.5 & 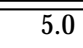 & 111.5 & 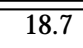 & $\begin{array}{l}-- \\
\end{array}$ & 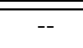 & $\begin{array}{l}-- \\
\end{array}$ & $\begin{array}{l}-- \\
\end{array}$ & $\begin{array}{l}-- \\
\end{array}$ & 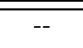 & 38.2 & 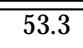 & 26.7 & $\overline{77.2}$ \\
\hline & Orthophosphorus & .4 & .4 & .4 & .4 & .8 & .4 & -- & -- & -- & -- & -- & -- & .4 & .4 & .4 & .4 \\
\hline \multirow[t]{2}{*}{$72-96$} & Nitrate & 17.3 & 37.5 & 33.9 & 8.6 & -- & 23.1 & -- & -- & -- & -- & -- & -- & -- & 24.5 & 18.7 & .3 \\
\hline & Orthophosphorus & .4 & .4 & .4 & .4 & -- & .4 & -- & -- & -- & -- & -- & -- & -- & .4 & .4 & .4 \\
\hline
\end{tabular}

${ }^{1} 0-48$ in depth is sum of $0-8,8-24,24-36$, and $36-48$ values and is considered the rooting zone for row crops. 
Table 11. Amounts of ammonia and ammonia plus organic nitrogen in soil samples from four farms in the Nutrient-Management Subbasin, in pounds per acre per depth

$[--$, no data]

\begin{tabular}{|c|c|c|c|c|c|c|c|c|c|c|c|c|c|c|c|c|c|}
\hline \multirow{2}{*}{$\begin{array}{l}\text { Depth } \\
\text { (inches) }\end{array}$} & \multirow[b]{2}{*}{ Constituent } & \multicolumn{4}{|c|}{ Farm D } & \multicolumn{4}{|c|}{ Farm F } & \multicolumn{4}{|c|}{ Farm H } & \multicolumn{4}{|c|}{ Farm M } \\
\hline & & $\begin{array}{l}\text { Spring } \\
1990\end{array}$ & $\begin{array}{l}\text { Fall } \\
1990\end{array}$ & $\begin{array}{l}\text { Spring } \\
1991\end{array}$ & $\begin{array}{l}\text { Fall } \\
1991\end{array}$ & $\begin{array}{l}\text { Spring } \\
1990\end{array}$ & $\begin{array}{l}\text { Fall } \\
1990\end{array}$ & $\begin{array}{l}\text { Spring } \\
1991\end{array}$ & $\begin{array}{l}\text { Fall } \\
1991\end{array}$ & $\begin{array}{l}\text { Spring } \\
1990\end{array}$ & $\begin{array}{c}\text { Fall } \\
1990\end{array}$ & $\begin{array}{l}\text { Spring } \\
1991\end{array}$ & $\begin{array}{l}\text { Fall } \\
1991\end{array}$ & $\begin{array}{l}\text { Spring } \\
1990\end{array}$ & $\begin{array}{l}\text { Fall } \\
1990\end{array}$ & $\begin{array}{l}\text { Spring } \\
1991\end{array}$ & $\begin{array}{l}\text { Fall } \\
1991\end{array}$ \\
\hline \multirow[t]{2}{*}{$0-8$} & Ammonia & 20.9 & 8.4 & 9.1 & 5.3 & 21.6 & 6.5 & 9.6 & 8.6 & 9.8 & 13.2 & 20.7 & 9.4 & 13.5 & 13.7 & 10.6 & 5.0 \\
\hline & $\begin{array}{l}\text { Ammonia plus } \\
\text { organic nitrogen }\end{array}$ & 3,950 & 2,860 & -- & 3,100 & 3,690 & 3,230 & -- & 2,830 & 3,280 & 3,230 & -- & 2,910 & 5,030 & 4,600 & -- & 4,420 \\
\hline \multirow[t]{2}{*}{$8-24$} & Ammonia & 14.4 & 15.4 & 13.4 & 7.7 & 20.7 & 22.1 & 14.4 & 6.7 & 8.2 & 27.9 & 13.4 & 3.8 & 19.2 & 21.1 & 16.3 & 3.4 \\
\hline & $\begin{array}{l}\text { Ammonia plus } \\
\text { organic nitrogen }\end{array}$ & 5,590 & 4,220 & -- & 5,940 & 4,430 & 3,270 & -- & 2,840 & 2,140 & 1,820 & -- & 1,470 & 4,570 & 4,320 & -- & 3,590 \\
\hline \multirow[t]{2}{*}{$24-36$} & Ammonia & 10.1 & 23.1 & 9.4 & 4.0 & 14.1 & 23.1 & 6.5 & 6.8 & 5.8 & 24.9 & 4.3 & 2.9 & 13.3 & 26.3 & 13.0 & 3.6 \\
\hline & $\begin{array}{l}\text { Ammonia plus } \\
\text { organic nitrogen }\end{array}$ & 3,110 & 3,280 & -- & 2,670 & 2,160 & 1,280 & -- & 920 & 1,090 & 740 & -- & 820 & 3,560 & 3,080 & -- & 3,030 \\
\hline \multirow[t]{2}{*}{$36-48$} & Ammonia & 10.8 & 18.4 & 7.2 & 3.2 & 13.0 & 19.1 & 4.3 & 72.8 & 6.5 & 18.4 & -- & 2.5 & 15.1 & 19.8 & 9.4 & 5.0 \\
\hline & $\begin{array}{l}\text { Ammonia plus } \\
\text { organic nitrogen }\end{array}$ & 3,210 & 2,440 & -- & 1,850 & 1,270 & 730 & -- & 870 & 470 & 600 & -- & 560 & 4,240 & 3,410 & -- & 3,910 \\
\hline \multirow[t]{2}{*}{${ }^{1} 0-48$} & Ammonia & 56.2 & 65.3 & 39.1 & 20.2 & 69.4 & 70.8 & 34.8 & 94.9 & 30.3 & 84.4 & 38.4 & 18.6 & 61.1 & 80.9 & 49.3 & 17.0 \\
\hline & $\begin{array}{l}\text { Ammonia plus } \\
\text { organic nitrogen }\end{array}$ & 15,900 & 12,800 & -- & 13,600 & 11,600 & 8,510 & -- & 7,460 & 6,980 & 6,390 & -- & 5,750 & 17,400 & 15,400 & -- & 15,000 \\
\hline \multirow[t]{2}{*}{$48-72$} & Ammonia & 23.1 & 40.4 & 14.4 & 6.4 & 24.5 & 37.5 & -- & -- & -- & -- & -- & -- & 28.1 & 35.3 & 14.4 & 5.8 \\
\hline & $\begin{array}{l}\text { Ammonia plus } \\
\text { organic nitrogen }\end{array}$ & 4,450 & 1,950 & -- & 1,960 & 2,590 & 990 & -- & -- & -- & -- & -- & -- & 6,970 & 3,870 & -- & 2,850 \\
\hline \multirow[t]{2}{*}{$72-96$} & Ammonia & 20.9 & 46.1 & 10.1 & 5.0 & -- & 32.4 & -- & -- & -- & -- & -- & -- & -- & 36.8 & 10.1 & 2.2 \\
\hline & $\begin{array}{l}\text { Ammonia plus } \\
\text { organic nitrogen }\end{array}$ & 1,760 & 1,330 & -- & 740 & -- & 970 & -- & -- & -- & -- & -- & -- & -- & 1,830 & -- & 1,140 \\
\hline
\end{tabular}

${ }^{1} 0-48$ in depth is sum of $0-8,8-24,24-36$, and $36-48$ values and is considered the rooting zone for row crops. 

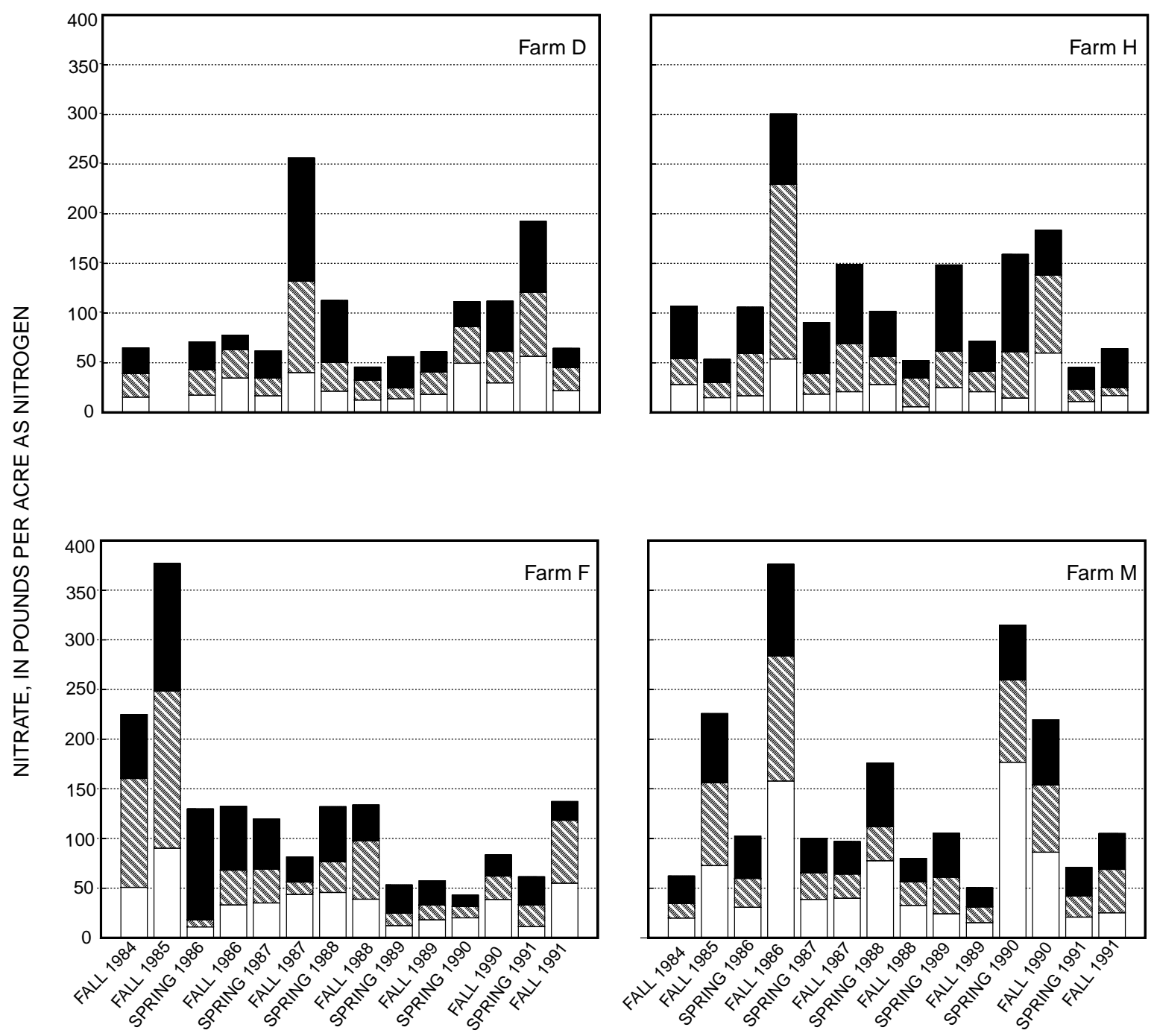

EXPLANATION

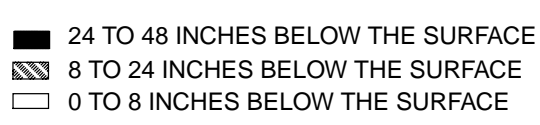

Figure 6. Amounts of soluble nitrate, as nitrogen, in the top 4 feet of soil prior to and during nutrient management at farms D, F, H, and M in the Nutrient-Management Subbasin. 

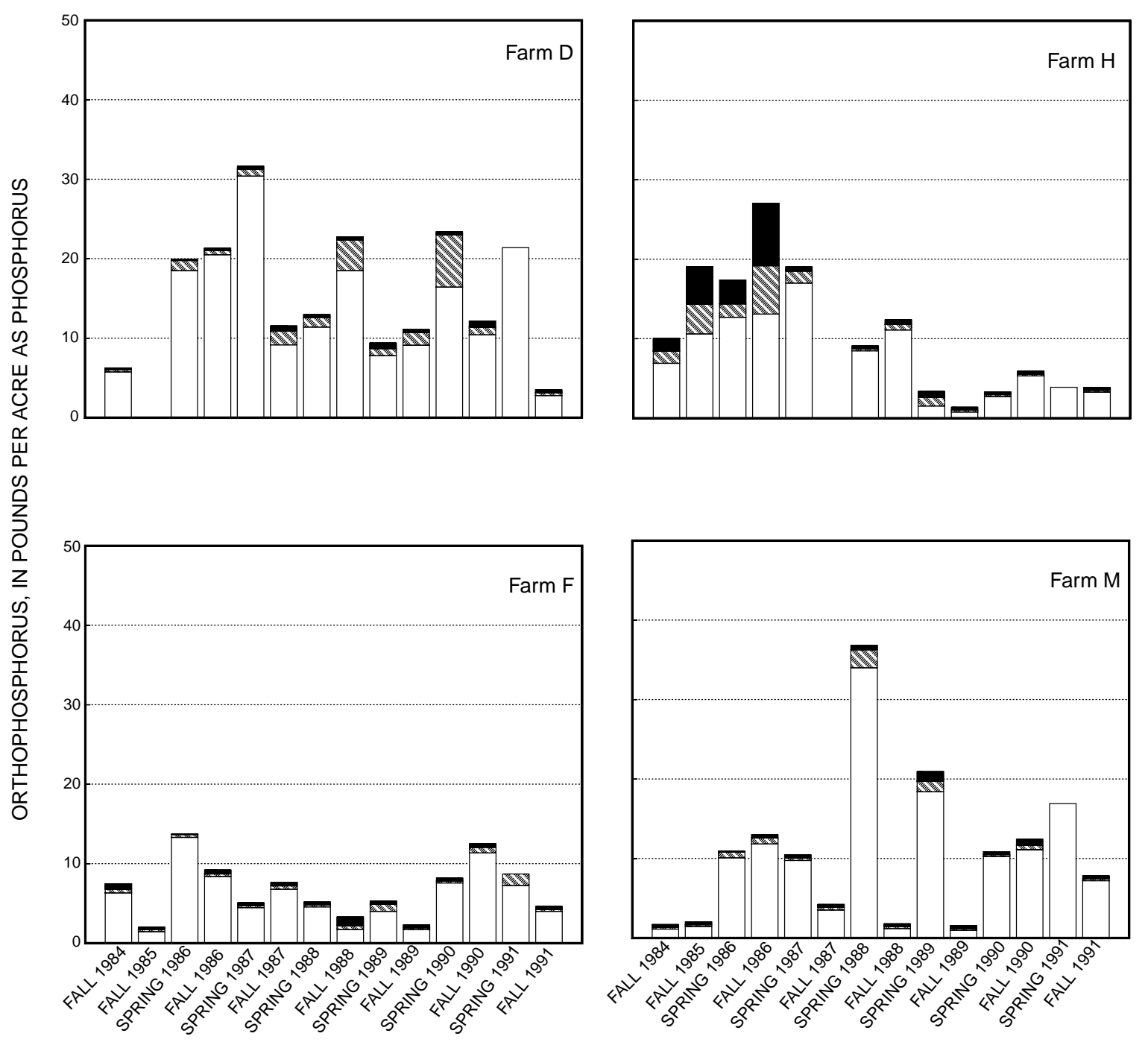

EXPLANATION

24 TO 48 INCHES BELOW THE SURFACE 8 TO 24 INCHES BELOW THE SURFACE $\square 0$ TO 8 INCHES BELOW THE SURFACE

Figure 7. Amounts of soluble orthophosphorus, as phosphorus, in the top 4 feet of soil prior to and during nutrient management at farms D, F, H, and M in the Nutrient-Management Subbasin. 
Substantial amounts of all nitrogen forms at depth in the soil column indicate that nitrogen remains available for conversion to nitrate and leaching to the ground water. The recommended maximum amount of nitrate nitrogen in the top $48 \mathrm{in}$. of soil at the end of the growing season is $100 \mathrm{lb} / \mathrm{acre}$, and $50 \mathrm{lb} / \mathrm{acre}$ is preferred in limestone derived soils for ground-water protection (Dale Baker, The Pennsylvania State University, written commun., 1989). Moreover, a possible effect of these nitrogen reserves would be to buffer short-term changes in nitrate concentrations in ground water and stream base flow.

\section{Crops}

Of the 2,500 acres of farmland in the Small Watershed, approximately 2,100 acres were planted in crops. Corn and alfalfa were cultivated on most of the acreage, along with minor amounts of small grains, tobacco, and produce (table 12). A comparison of 1989-91 land use and crop acreages in the NutrientManagement Subbasin to those reported by Koerkle and others (1996) for 1984-86 showed minor change. Cropland remained nearly constant at 560 acres overall. Corn acreage decreased 10 percent accompanied by an increase in other crops and pasture. Because corn received the largest nitrogen applications, a decrease in corn acreage was edxpected to result in a decrease in nitrogen applications in the subbasin.

\section{CHANGES IN SURFACE-WATER QUALITY AFTER NUTRIENT MANAGEMENT}

Monitoring conducted from 1984 to 1989 was extended from 1989 through 1991 to improve the probability of detecting the effects, if any, of nutrient management on water quality in the Small Watershed. Preliminary data from the 1984-89 study indicated that reserves of residual nitrogen in the soil and time delays between infiltration of nitrogen at the soil surface and discharge of nitrogen in base flow were possible reasons why previous monitoring did not detect substantial changes in water quality. In view of recent work at a hydrologically similar site in the Conestoga River Basin (Hall and others, 1996), the time lags between changes in surface applications of nitrogen and measurable changes in base-flow surface-water quality, if any, were expected to be within the 5-year extended post-implementation monitoring period.

Nitrogen, phosphorus, and suspended sediment were the constituents monitored in surface-water base flow and stormflow in the Small Watershed. Data from 1989 through 1991 for these constituents are presented in this section. Nitrogen was the predominant chemical constituent in surface-water base flow and stormflow in the Small Watershed. The predominant forms of nitrogen were dissolved nitrate plus nitrite in base flow and total ammonium plus organic nitrogen in stormflow. Because nitrogen was also the constituent for which nutrient-management plans were constructed, the focus of the following discussion is on nitrogen. Suspended sediment was not expected to be affected by nutrient management but is an important nonpoint-source contaminant in the Small Watershed and is included for completeness. Complete chemical water-quality data from the study sampling sites have been published in USGS WaterData Reports for 1990 and 1991 (Loper and others, 1991; Durlin and Schaffstall, 1992).

\section{Base Flow}

Data are presented for all the constituents sampled in base flow, but greater emphasis was placed on dissolved nitrate plus nitrite as an indicator of the effects of nutrient management for reasons presented by Koerkle and others (1996). Those reasons are that nitrate plus nitrite in base flow (1) contributed most of the nitrogen load, (2) was a composite of ground-water contributions of nitrate plus nitrite from all locations within the watershed, (3) was least affected by in-stream disturbance during sampling, and (4) showed much less variability than in stormflow. 
Table 12. Percentage of land use and crop coverage in the

Small Watershed and Nutrient-Management Subbasin, 1989-91, and in the Nutrient-Management Subbasin, 1984-86

\begin{tabular}{lccc}
\hline \multirow{2}{*}{ Crop } & \multicolumn{3}{c}{ Percentage of agricultural acreage } \\
\cline { 2 - 4 } & $\begin{array}{c}\text { Nutrient- } \\
\text { Small Watershed, } \\
1989-91\end{array}$ & $\begin{array}{c}\text { Nutrient- } \\
\text { Management } \\
\text { Subbasin, } \\
\text { Management } \\
\text { Subbasin, } \\
1989-91\end{array}$ \\
\hline Corn & 38 & 42 & 52 \\
Hay & 24 & 26 & 22 \\
Other crops & 9 & 12 & 4 \\
Pasture & 13 & 12 & 8 \\
Other noncrop uses & 16 & 8 & 14 \\
\hline
\end{tabular}

${ }^{1}$ Values for April 1984 through March 1986 from Koerkle and others (1996).

\section{Nitrogen}

Concentrations of nitrogen in base flow are summarized in figures 8 and 9. In all instances, median concentrations of nitrogen in base flow were lowest at site NM1 and greatest at site NM5. Median concentrations of dissolved ammonium ranged from 0.02 to $0.11 \mathrm{mg} / \mathrm{L}$. The median concentration of dissolved ammonium (fig. 8) at sites NM1 and NC1, 0.03 and $0.02 \mathrm{mg} / \mathrm{L}$ as nitrogen, respectively, were almost identical although the range of concentrations at site NC1 was greater. Given land use in the Nonnutrient-Management Subbasin, a larger median concentration was expected. Median concentrations of total ammonium plus organic nitrogen (fig. 9) were between 1.1 and $1.3 \mathrm{mg} / \mathrm{L}$ at all sites except site NM1.

Median concentrations of dissolved nitrate plus nitrite (fig. 8) ranged from 3.2 to $8.0 \mathrm{mg} / \mathrm{L}$ and were positively correlated with percentage of agricultural land use in the contributing drainage area. Site NM1, the mostly forested site, had the lowest median concentration $(3.2 \mathrm{mg} / \mathrm{L}$ as nitrogen) and the lowest range in concentrations. Site NM5 had the greatest agricultural land use (78 percent) and the greatest median concentration of dissolved nitrate plus nitrite $(8 \mathrm{mg} / \mathrm{L}$ as nitrogen). Site NC1, the NonnutrientManagement Subbasin, had a median concentration about midway, $4.9 \mathrm{mg} / \mathrm{L}$ as nitrogen and 59 percent agricultural land use. Site SW1 had 68 percent agricultural land use and a $7.5 \mathrm{mg} / \mathrm{L}$ as nitrogen median concentration of dissolved nitrate plus nitrite. The greatest range of concentrations occurred at site SW1, the most downstream site, and was possibly a result of unequal contributions of tributary waters with different water quality, such as sites NM5 and NC1. Maximum concentrations of dissolved nitrate plus nitrite were lower than concentrations measured from 1984 to 1989 at all sites except site SW1.

The U.S. Environmental Protection Agency (1996) Maximum Contaminant Level for nitrate plus nitrite in drinking water is $10 \mathrm{mg} / \mathrm{L}$ as nitrogen. Concentrations greater than or equal to $10 \mathrm{mg} / \mathrm{L}$ of dissolved nitrate plus nitrite as nitrogen occurred once at site NM5 and twice at site SW1.

Base-flow concentrations from 1989 to 1991 and from 1984 to 1986 (pre-nutrient management) were compared by use of a seasonally grouped Mann-Whitney rank-sum test. The seasonal groups selected for base-flow concentrations were months of the year. Because the median concentration in some of the constituents of interest, principally dissolved nitrate plus nitrite, varies monthly as part of an annual seasonal cycle, grouping data by month removes much of this seasonal variation. Reduced variation in the data increases the power of the step-trend test to detect trends. Results from individual seasons are combined into a single overall result for each constituent. Data from the 1986-89 early nutrientmanagement period were deleted from the test data set in order to have more uniform climatic and hydrologic conditions in the before- and during-nutrient-management data groups and to minimize transition effects caused by probable time lags in the response of water quality to nutrient management. 


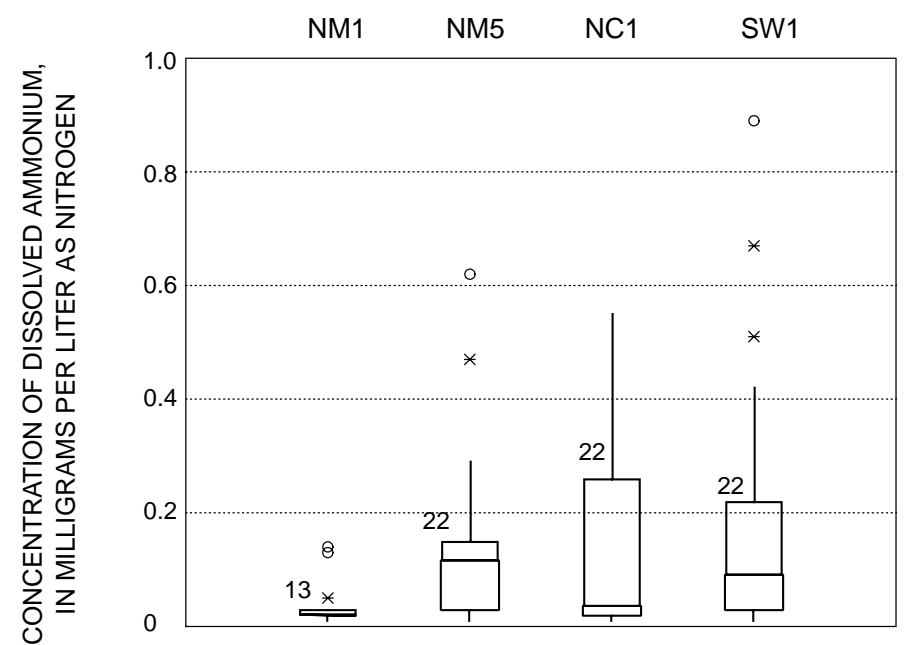

\section{EXPLANATION}

Far-outside values-plotted individually, all points greater than 3 times the interquartile range

* Outside values_-plotted individually, points 1.5 to 3 times greater than the interquartile range

Upper adjacent value equals largest data point less than or equal to the upper quartile plus 1.5 times the interquartile range

Number of samples

$\mathrm{N}$ 75th percentile

Upper quartile

Median (50th percentile)

Lower quartile

25th percentile

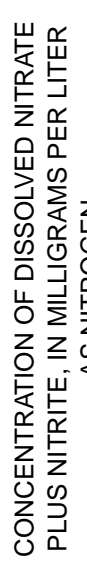

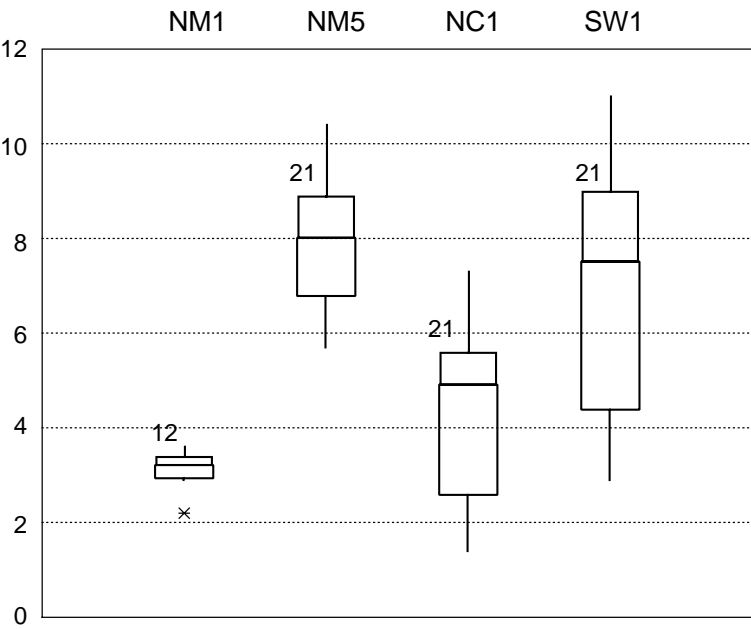

Lower adjacent value equals smallest data point greater than or equal to the lower quartile minus 1.5 times the interquartile range

Figure 8. Concentrations of dissolved ammonium and dissolved nitrate plus nitrite in base flow at sites NM1, NM5, NC1, and SW1 in the Small Watershed from October 1989 through September 1991. 


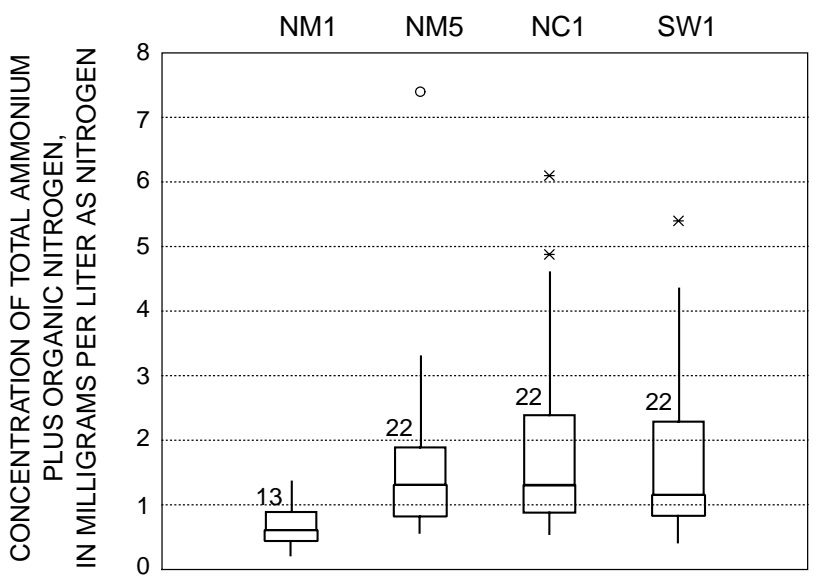

* Outside values - plotted individually, points 1.5 to 3 times greater than the interquartile range

Upper adjacent value equals largest data point less than or equal to the upper quartile plus 1.5 times the interquartile range

$\mathrm{N}$ Number of samples

75th percentile

Upper quartile

Median (50th percentile)

Lower quartile

25th percentile

Lower adjacent value equals smallest data point greater than or equal to the lower quartile minus 1.5 times the interquartile range

Figure 9. Concentrations of total ammonium plus organic nitrogen in base flow at sites NM1, NM5, NC1, and SW1 in the Small Watershed from October 1989 through September 1991.

Results of the Mann-Whitney test show few significant step trends in nitrogen (table 13). At site $\mathrm{NM} 1$, the median flow-adjusted concentration of dissolved nitrate plus nitrite increased about $0.4 \mathrm{mg} / \mathrm{L}$ or about 15 percent. The cause of the increase is not known, although minor deforestation did occur upstream of the site during the study period. A $0.03 \mathrm{mg} / \mathrm{L}$ (50 percent) decrease in the median concentration of dissolved ammonium also was detected at site NC1. Comparison to step-trend test results reported by Koerkle and others (1996) shows the only consistent step trend across the 1986-89 early nutrient-management period and the 1989-91 extended nutrient-management period to be a decrease in dissolved ammonium at site NC1.

Koerkle and others (1996) noted that negative trend coefficients for dissolved nitrate plus nitrite at site NM5, the Nutrient-Management Subbasin, suggested nutrient management had some effect on concentrations of dissolved nitrate plus nitrite. Whereas at site NC1, the Nonnutrient-Management Subbasin, and site SW1, the Small Watershed, trend coefficients were positive. Following their reasoning, it could be argued that nutrient management continues to show a small (step-trend coefficient <-.01) effect on flow-adjusted concentrations of dissolved nitrate plus nitrite. However, the low confidence ( $\mathrm{p}$-value $=$ 0.79) associated with this coefficient and a return after 1988 to near pre-nutrient management nitrogen application amounts does not strengthen this argument. Further ambiguity is added because the significant trends were of short duration and possibly represent normal variation in hydrologic and nearor in-stream conditions rather than the effects of nutrient management. Climate and localized land use are examples of factors that show substantial variability and can affect water quality but are not related to nutrient management.

A paired-subbasin comparison of base-flow concentrations of dissolved nitrate plus nitrite from the 1984-86 pre-nutrient-management period and 1989-91 extended nutrient-management period also suggests no change during nutrient management. A plot of concentrations of dissolved nitrate plus nitrite at site NM5, the Nutrient-Management Subbasin, against concentrations at site NC1, the NonnutrientManagement Subbasin (fig. 10), shows no distinct separation in the data from the two periods. Further, analysis of covariance of the relation detected no significant difference $\left(0.74[\mathrm{~F}]<4.05\left[\mathrm{~F}_{\text {crit }}\right]\right)$ in the relation between concentrations of dissolved nitrate plus nitrite in the two subbasins across the two periods. However, this lack of significance does not preclude a simultaneous increase or decrease in both subbasins. When taken together, however, results of the Mann-Whitney rank-sum test and the analysis of covariance suggest no significant change in concentrations of dissolved nitrate plus nitrite in base flow from 1984-86 to 1989-91, which is in contrast to the analysis presented by Koerkle and others (1996). 
Table 13. Results of seasonal Mann-Whitney rank-sum test for step trends from April 1984 through March 1986 to October 1989 through September 1991 in unadjusted and flow-adjusted concentrations of nutrient and suspended sediment in base flow in the Small Watershed

[n, number of data points; $\mathrm{mg} / \mathrm{L}$, milligrams per liter; <, less than; --, not applicable]

\begin{tabular}{|c|c|c|c|c|c|}
\hline \multirow[b]{2}{*}{ Constituent } & \multirow[b]{2}{*}{$\mathrm{n}$} & \multicolumn{2}{|c|}{ Unadjusted data } & \multicolumn{2}{|c|}{ Flow-adjusted data } \\
\hline & & $\begin{array}{l}\text { Step trend } \\
(\mathrm{mg} / \mathrm{L})\end{array}$ & Probability & $\begin{array}{l}\text { Step trend } \\
(\mathrm{mg} / \mathrm{L})\end{array}$ & Probability \\
\hline \multicolumn{6}{|l|}{ Site NM1 } \\
\hline Dissolved nitrate plus nitrite & 42 & 0.48 & $1_{<0.01}$ & 0.41 & ${ }^{1} 0.01$ \\
\hline Dissolved ammonium & 43 & $<.01$ & .31 & -- & -- \\
\hline Total ammonia plus organic nitrogen & 43 & .18 & .20 & -- & -- \\
\hline Total phosphorus & 43 & -.02 & ${ }^{1}<.01$ & -.01 & ${ }^{1} .02$ \\
\hline Suspended sediment & 41 & $<.01$ & .84 & -- & -- \\
\hline \multicolumn{6}{|l|}{$\underline{\text { Site NM5 }}$} \\
\hline Dissolved nitrate plus nitrite & 49 & .08 & .79 & $<-.01$ & .79 \\
\hline Dissolved ammonium & 50 & $<.01$ & .90 & -- & -- \\
\hline Total ammonia plus organic nitrogen & 50 & .22 & .12 & -- & -- \\
\hline Total phosphorus & 50 & -.01 & .52 & .02 & .44 \\
\hline Suspended sediment & 50 & 19.5 & ${ }^{1} .02$ & -- & -- \\
\hline \multicolumn{6}{|l|}{ Site NC1 } \\
\hline Dissolved nitrate plus nitrite & 50 & .45 & .52 & -.08 & 1.00 \\
\hline Dissolved ammonium & 51 & -.03 & $1<.01$ & -- & -- \\
\hline Total ammonia plus organic nitrogen & 51 & .04 & .61 & -- & -- \\
\hline Total phosphorus & 51 & -.02 & .17 & $<.01$ & .59 \\
\hline Suspended sediment & 49 & -5.00 & ${ }^{1} .05$ & -- & -- \\
\hline \multicolumn{6}{|l|}{ Site SW1 } \\
\hline Dissolved nitrate plus nitrite & 51 & .75 & .24 & .56 & .20 \\
\hline Dissolved ammonium & 52 & -.02 & .53 & -- & -- \\
\hline Total ammonia plus organic nitrogen & 52 & .08 & .80 & -- & -- \\
\hline Total phosphorus & 52 & -.02 & .53 & .06 & .08 \\
\hline Suspended sediment & 51 & 1.00 & .52 & -- & -- \\
\hline
\end{tabular}

${ }^{1}$ Significant at the 95-percent confidence level. 


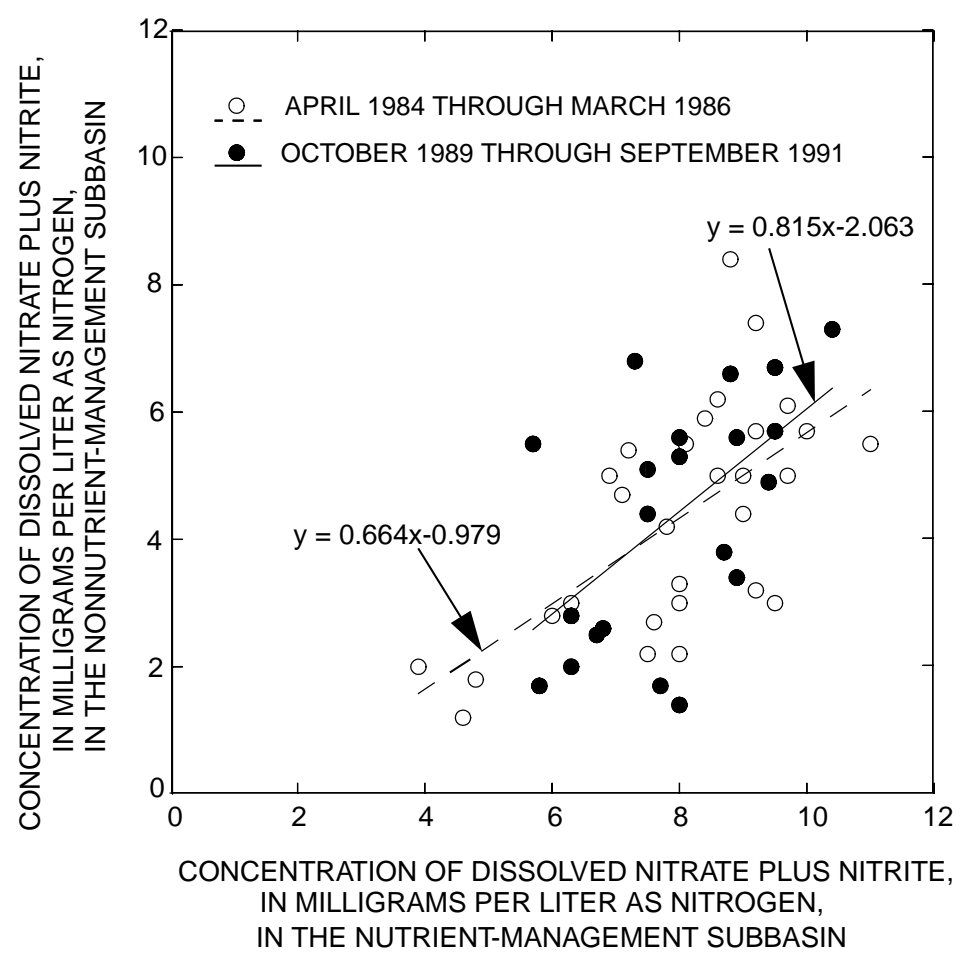

Figure 10. Relation between concentrations of dissolved nitrate plus nitrite in base flow from the Nutrient-Management Subbasin (NM5) and in base flow from the Nonnutrient-Management Subbasin (NC1).

Examination of time-series plots of dissolved nitrate plus nitrite data from April 1984 through September 1991 (fig. 11) helps explain the change in trend coefficients for the study period. Locallyweighted scatterplot smoothing (LOWESS)(Helsel and Hirsch, 1992) is overlain on the plots to show movement over time of the center of the data. From 1984 through 1989, dissolved nitrate plus nitrite data at sites SW1 and NC1 suggest increasing concentrations, and data at sites NM1 and NM5 suggest decreasing concentrations. From 1989 to 1991, the LOWESS smooths for all sites reversed direction, although the change at site NM5 was small and appears to have begun in 1988. Possible reasons for the decreasing concentrations at sites NC1 and SW1 include the increased number of nutrient-management plans in both basins and reduced streamflow in 1989-91. Comparing monthly mean streamflows (fig. 2) and the LOWESS plot for concentrations of dissolved nitrate plus nitrite in base flow show both tend to decrease in 1989-91 at sites NC1 and SW1. At site NM5, the smooth shows a return in 1989-91 to concentrations typical of before nutrient management. Nutrient-application data also showed a return in 1989-91 to nitrogen application amounts closer to pre-nutrient-management amounts. At site NM1, the LOWESS smooth suggests increasing concentrations as did the step-trend test. Because of the large variation in the data, none of the LOWESS movements were significant step trends, except at site NM1, where variance is much less.

Comparison of the LOWESS smooth of concentrations of dissolved nitrate plus nitrite at site NM5 to annual applied nitrogen quantities in the Nutrient-Management Subbasin (fig. 5) shows a $0.5 \mathrm{mg} / \mathrm{L}$ decrease in concentrations corresponding to decreased nitrogen applications, which averaged about 30 percent from 1986 to 1989 as reported by Koerkle and others (1996). The decrease was short term as were the decreases in applied nitrogen. Also, a portion of the decrease could have been partially masked by a streamflow driven increase in concentration, as seen at sites NC1 and SW1. 

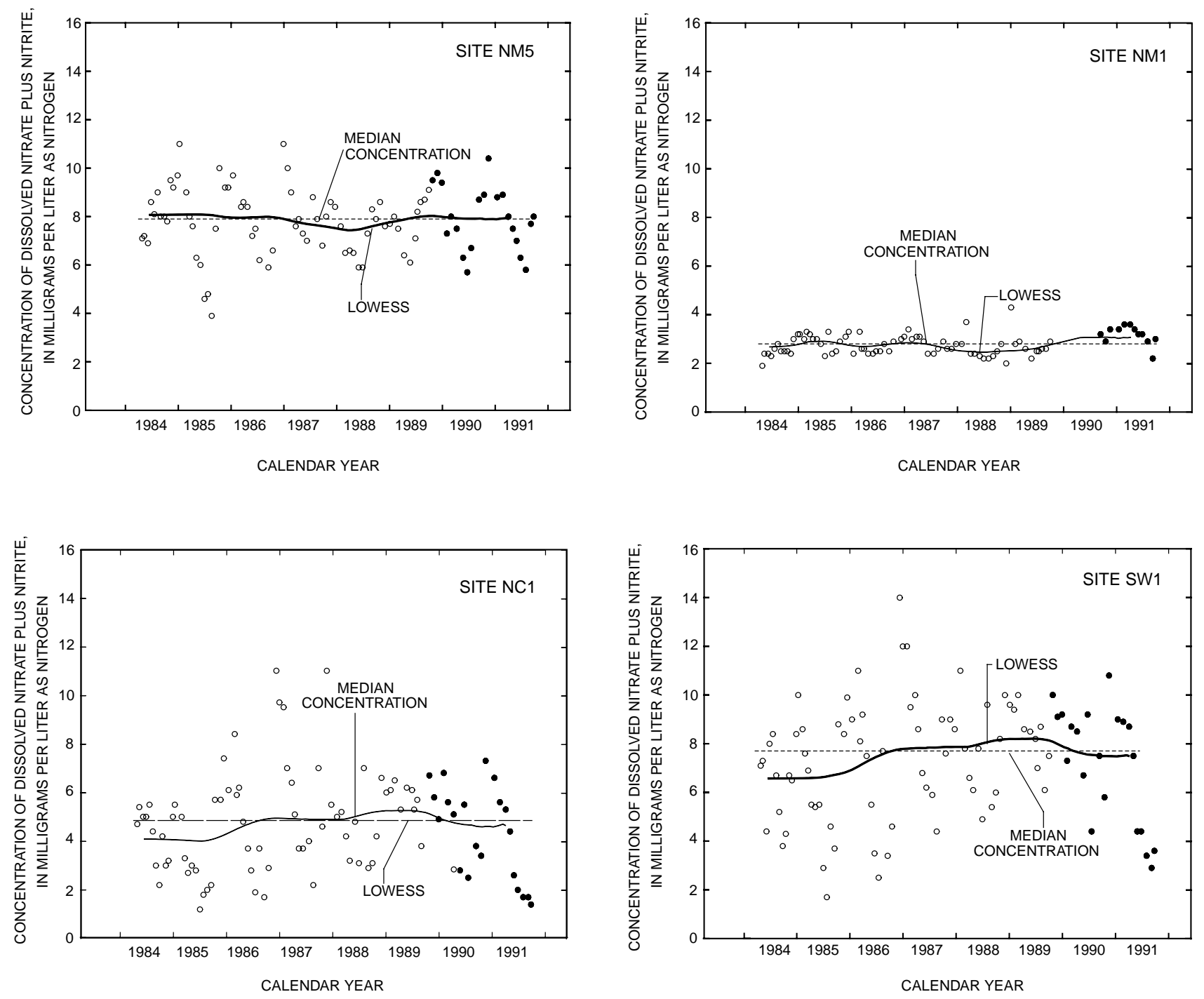

EXPLANATION

- APRIL 1984 THROUGH SEPTEMBER 1989

- OCTOBER 1989 THROUGH SEPTEMBER 1991

Figure 11. Dissolved nitrate plus nitrite concentrations in base flow at sites NM1 and NM5 in the Nutrient-Management Subbasin, site NC1 in the Nonnutrient-Management Subbasin, and site SW1 in the Small Watershed. 


\section{Phosphorus}

Median concentrations of total phosphorus ranged from $0.04 \mathrm{mg} / \mathrm{L}$ at site NM1 to $0.24 \mathrm{mg} / \mathrm{L}$ at site NC1 (fig. 12). Results of the seasonally-grouped Mann-Whitney test (table 13) comparing base-flow concentrations of phosphorus from 1989 to 1991 to concentrations from 1984 to 1986 (pre-nutrient management) showed one significant step trend. Median flow-adjusted concentrations of total phosphorus at site NM1 decreased $0.01 \mathrm{mg} / \mathrm{L}$ (20 percent).

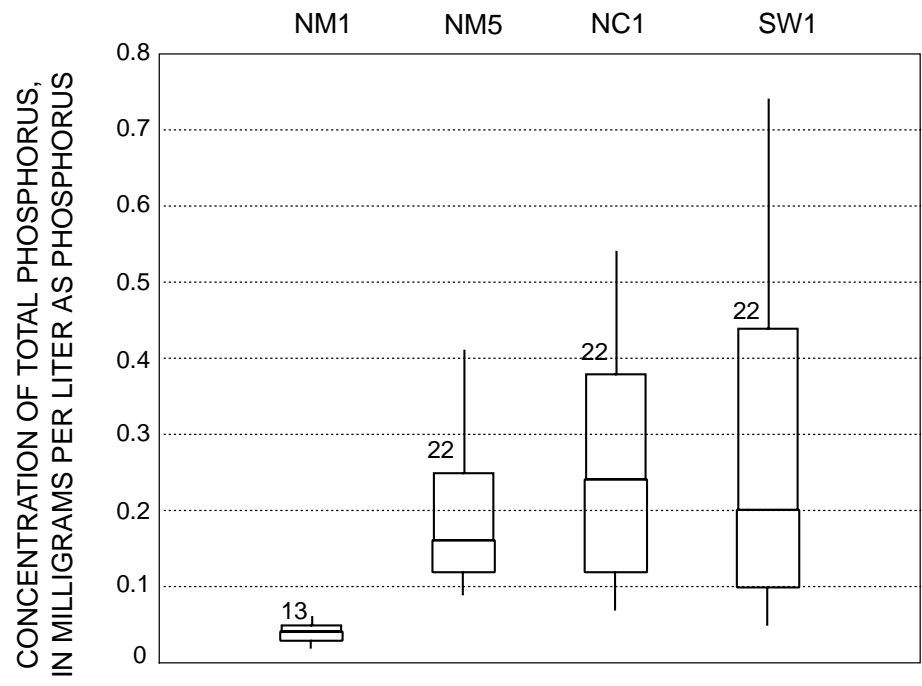

EXPLANATION

Far-outside values-plotted individually, all points greater than 3 times the interquartile range

* Outside values - plotted individually, points 1.5 to 3 times greater than the interquartile range

Upper adjacent value equals largest data point less than or equal to the upper quartile plus 1.5 times the interquartile range

$\mathrm{N}$ Number of samples

75th percentile Upper quartile Median (50th percentile) Lower quartile 25th percentile

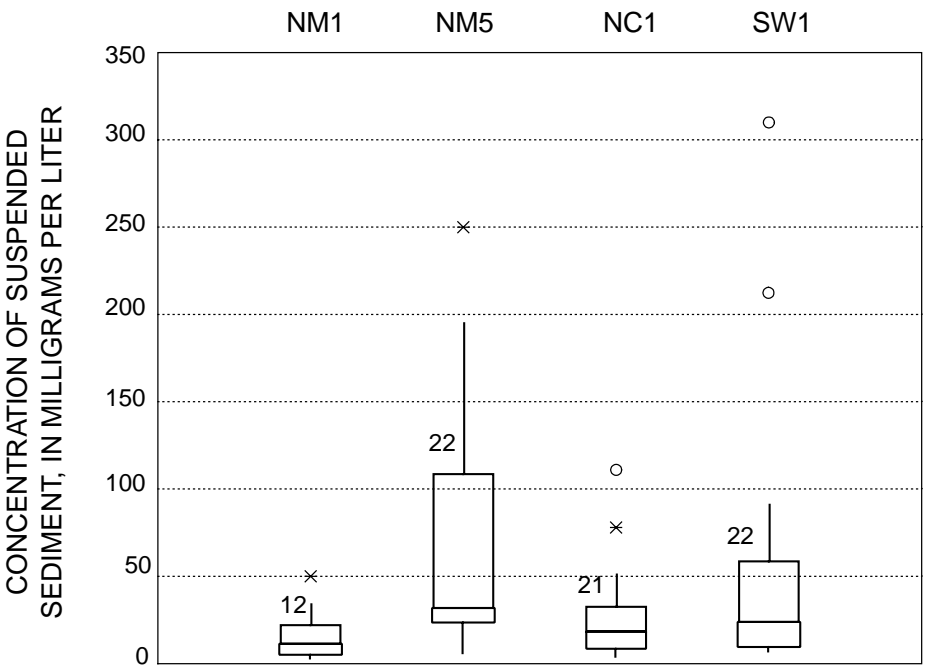

Lower adjacent value equals smallest data point greater than or equal to the lower quartile minus 1.5 times the interquartile range

Figure 12. Concentrations of total phosphorus and suspended sediment in base flow at sites NM1, NM5, NC1, and SW1 in the Small Watershed from October 1989 through September 1991. 


\section{Sediment}

Median concentrations of suspended sediment ranged from $11 \mathrm{mg} / \mathrm{L}$ at site NM1 to $31 \mathrm{mg} / \mathrm{L}$ at site NM5 (fig. 12). Variation in concentrations of suspended sediment was between 1 and 2 orders of magnitude and was greatest at site NM5. Animal access to the stream was easiest at site NM5 because of lower streambank heights. The reported distribution of suspended-sediment concentrations in base flow is probably biased toward larger concentrations. This bias is the result of sample collection occurring predominantly when animals were in pasture and were most likely to be disturbing streambed sediment. From about November through March, the bias is small or nonexistent because pasturing is minimal. Mann-Whitney test results showed a significant increase in the median concentration of suspended sediment of about $20 \mathrm{mg} / \mathrm{L}$ (160 percent) from 1984-86 to 1989-91 at site NM5, the outlet to the NutrientManagement Subbasin. In contrast, a $5 \mathrm{mg} / \mathrm{L}$ (20 percent) decrease in the median concentration of suspended sediment was detected at site NC1, the outlet of the Nonnutrient-Management Subbasin.

\section{Stormflow}

Stormflow water quality was sampled during a total of 41 stormflow events at site SW1 and 32 events at site NM5. Of that total, three storms at site SW1 and five storms at site NM5 were sampled for suspended sediment only. Fewer events were recorded at site NM5 because of nonuniform precipitation over the watershed, in particular, localized thunderstorms, and the smaller drainage area for site NM5, which resulted in a rise in stream stage less than the $0.10 \mathrm{ft}$ minimum established for stormflow events. Stormflow events were seasonally clustered. August was the most active month with 25 percent of all stormflow events. January was the second most active month with about 15 percent of all events. No stormflow events were sampled in February. Mean concentrations in sampled stormflow at sites SW1 and NM5 are summarized in figures 13 and 14.

Comparison of 1989-91 mean concentrations of constituents during stormflow to 1984-86 (prenutrient management) mean concentrations during stormflow shows no evidence that mean concentrations have declined after 5 years of nutrient management.

\section{Nitrogen}

Mean concentrations of total nitrate plus nitrite decreased and mean concentrations of total ammonium plus organic nitrogen increased during periods of stormflow. At site SW1, the median of mean concentrations of total nitrate plus nitrite during stormflow was 50 percent lower than the median concentration in base flow. The median mean-storm concentration of total ammonium plus organic nitrogen was 480 percent greater than the median concentration in base flow. At site NM5, the median of mean concentrations of total nitrate plus nitrite during stormflow was 65 percent lower than the median concentration in base flow. The median of mean concentrations of total ammonium plus organic nitrogen during stormflow was 460 percent greater than the median concentration in base flow.

During stormflow, results of Mann-Whitney rank-sum tests (table 14) show no significant change in mean concentrations of total nitrate plus nitrite or total ammonium plus organic nitrogen from 1984-86 to 1989-91. However, at a reduced confidence level (90 percent instead of 95 percent), a significant increase in mean concentrations of total ammonium plus organic nitrogen from $4.6 \mathrm{mg} / \mathrm{L}$ (1984-86) to $5.5 \mathrm{mg} / \mathrm{L}$ (198991) was indicated $(p-v a l u e=0.10)$. This increase in concentrations of total ammonium plus organic nitrogen could have resulted from a combination of time of occurrence for the stormflow events and nutrient management. A greater number of stormflow events in 1989-91 occurred in late summer through the fall when the availability of organic nitrogen is increased because of harvesting and seasonal vegetation die-back. In addition, under nutrient management, more frequent manure applications are generally consolidated into large applications after harvest and prior to planting. However, time of application may not have been a critical factor, as consolidated application methods require long-term manure storage, and the number of manure-storage facilities was limited. 


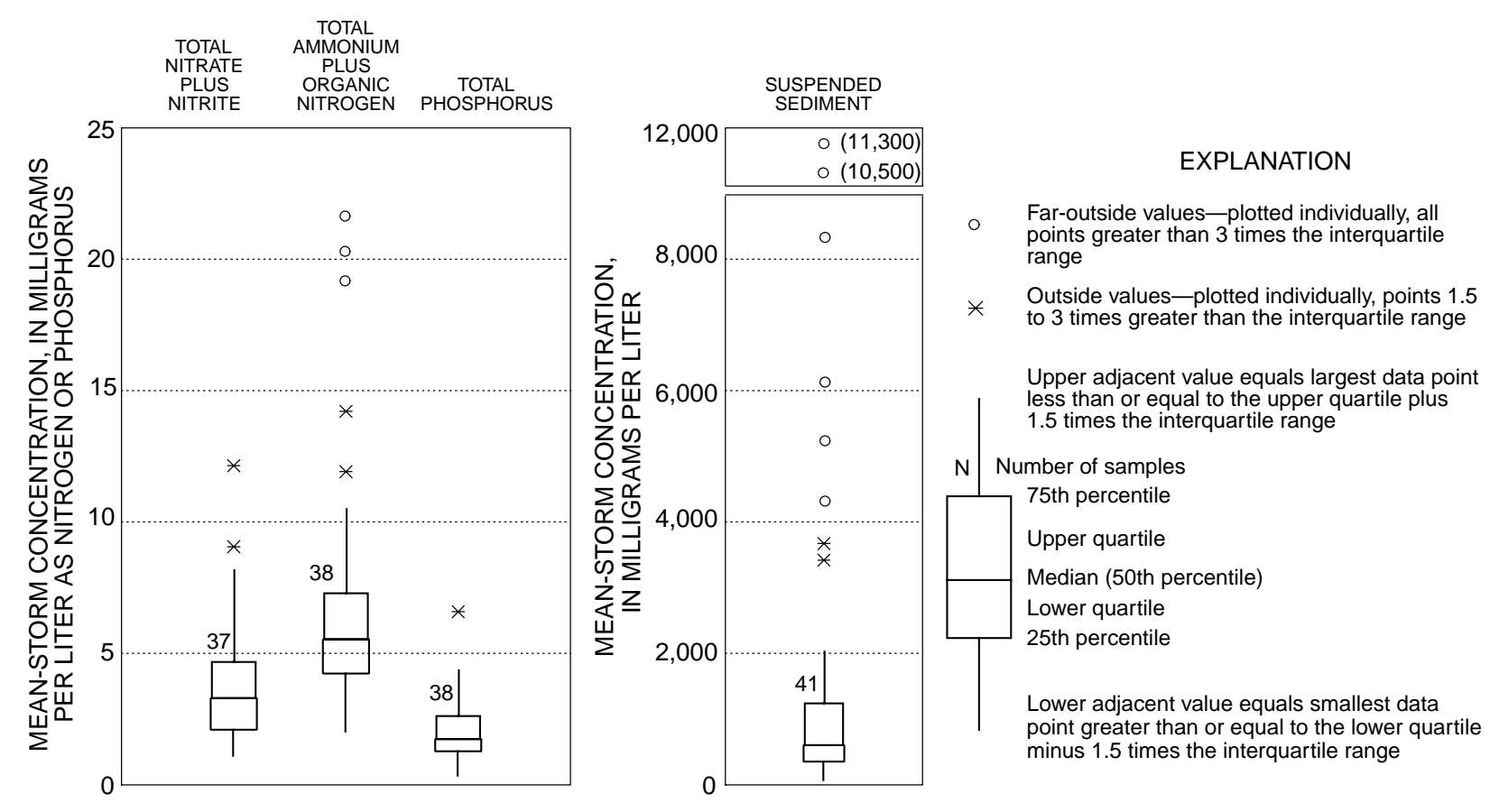

Figure 13. Mean concentrations of total nitrate plus nitrite, total ammonium plus organic nitrogen, total phosphorus, and suspended sediment in stormflow at site SW1 in the Small Watershed for the period October 1989 through September 1991.
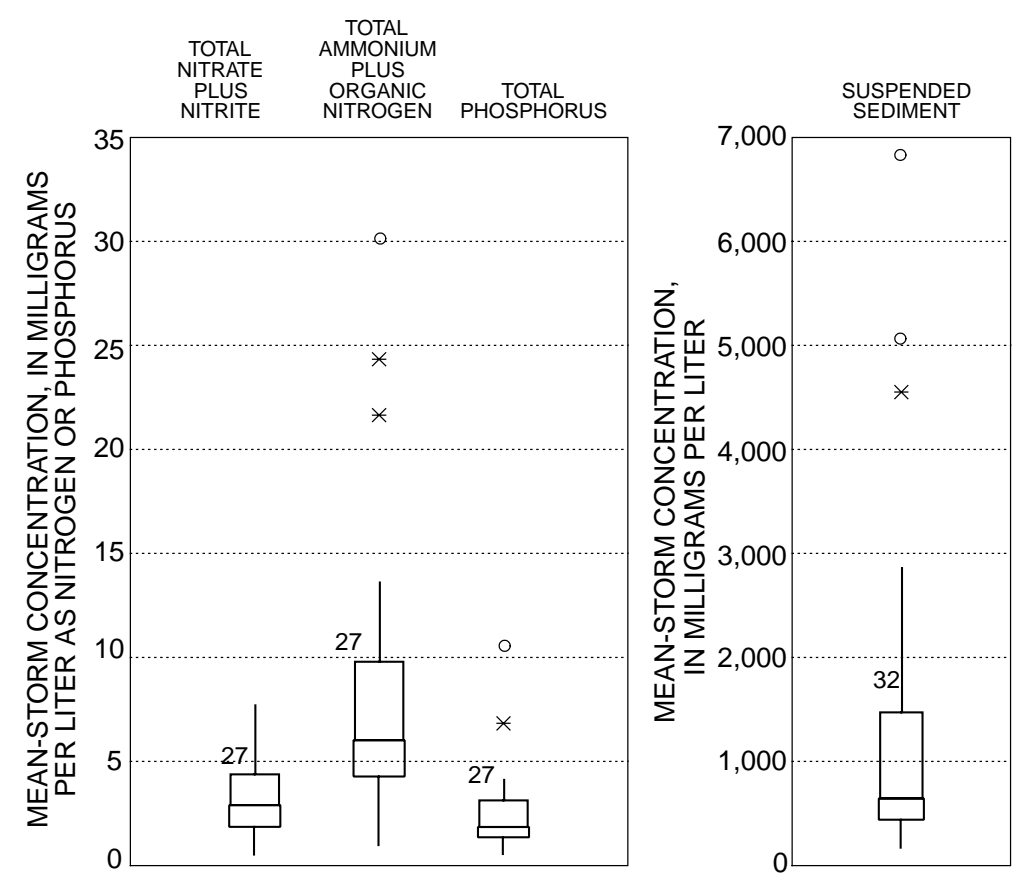

\section{EXPLANATION}

Far-outside values-plotted individually, all points greater than 3 times the interquartile range

* Outside values - plotted individually, points 1.5 to 3 times greater than the interquartile range

Upper adjacent value equals largest data point less than or equal to the upper quartile plus 1.5 times the interquartile range

$\mathrm{N}$ Number of samples

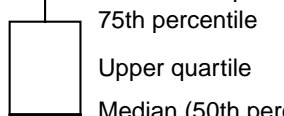

Median (50th percentile)

Lower quartile

25th percentile

Lower adjacent value equals smallest data point greater than or equal to the lower quartile minus 1.5 times the interquartile range

Figure 14. Mean concentrations of total nitrate plus nitrite, total ammonium plus organic nitrogen, total phosphorus, and suspended sediment in stormflow at site NM5 in Small Watershed for the period October 1989 through September 1991. 
Table 14. Results of Mann-Whitney rank-sum test of April 1984 to April 1986 (before nutrient management) and April 1989 to October 1991 mean concentrations of constituents during stormflow at sites SW1 and NM5 in the Small Watershed

[n, number of data points]

\begin{tabular}{|c|c|c|c|c|c|c|c|c|c|c|c|c|}
\hline \multirow{2}{*}{ Site } & \multirow[b]{2}{*}{$\mathrm{n}$} & \multicolumn{2}{|c|}{$\begin{array}{c}\text { Total nitrate plus } \\
\text { nitrite }\end{array}$} & \multirow[b]{2}{*}{$\mathrm{n}$} & \multicolumn{2}{|c|}{$\begin{array}{l}\text { Total ammonium } \\
\text { plus organic } \\
\text { nitrogen }\end{array}$} & \multirow[b]{2}{*}{$\mathrm{n}$} & \multicolumn{2}{|c|}{ Total phosphorus } & \multirow[b]{2}{*}{$\mathrm{n}$} & \multicolumn{2}{|c|}{$\begin{array}{l}\text { Suspended } \\
\text { sediment }\end{array}$} \\
\hline & & $\mathrm{p}$-value & $\begin{array}{l}\text { Step } \\
\text { trend }^{1}\end{array}$ & & $p$-value & $\begin{array}{l}\text { Step } \\
\text { trend }^{1}\end{array}$ & & $\mathrm{p}$-value & $\begin{array}{l}\text { Step } \\
\text { trend }^{1}\end{array}$ & & $\mathrm{p}$-value & $\begin{array}{l}\text { Step } \\
\text { trend }^{1}\end{array}$ \\
\hline SW1 & 70 & 0.88 & None & 70 & 0.10 & None & 70 & 0.52 & None & 80 & 0.32 & None \\
\hline NM5 & 66 & .63 & None & 66 & .62 & None & 66 & .98 & None & 63 & .28 & None \\
\hline
\end{tabular}

${ }^{1}$ Significant at the 95-percent confidence level; $p$-value $\leq 0.05$.

\section{Phosphorus}

Concentrations of total phosphorus increased with stormflow. At site SW1, the median of mean concentrations of total phosphorus during stormflow was 860 percent greater than the median concentration in base flow. At site NM5, the median of mean concentrations during stormflow was 1,100 percent greater than the median concentration in base flow. A rank-sum test (table 14) showed no significant change in mean concentrations of total phosphorus during stormflow from 1984-86 to 1989-91.

\section{Sediment}

Concentrations of suspended sediment also increased with stormflow. At site SW1, the median of mean concentrations of suspended sediment during stormflow was 2,500 percent greater than the median concentration in base flow. At site NM5, the median of mean concentrations of suspended sediment during stormflow was 2,000 percent greater than the median concentration in base flow. A rank-sum test (table 14) showed no significant change in mean concentrations of suspended sediment during stormflow from 1984-86 to 1989-91.

\section{Loads}

Monthly and annual loads for sites SW1 and NM5 are presented in tables 15 and 16. Maximum monthly loads for all constituents generally occurred during the months of November through January as did maximum monthly mean streamflows. Maximum monthly loads for the study period were lower than those reported by Koerkle and others (1996) for the first 3.5 years of nutrient management. This decrease in loads resulted from a decrease in monthly mean streamflows. Loads are dependent on streamflow as can be seen for nitrogen loads at site SW1 in figure 15. Because of this strong dependency, reductions or other changes in loads that result from nutrient management are likely to be unidentifiable from streamflow induced changes. Minimum monthly loads occurred during no particular time period but occurred at the same time for total nitrate plus nitrite and total ammonium plus organic nitrogen and at the same time for total phosphorus and suspended sediment. Minimum monthly mean streamflows correlated strongly with minimum monthly loads of total nitrate plus nitrite and total ammonium plus organic nitrogen but not with loads of total phosphorus and suspended sediment. Loads of suspended sediment and associated total phosphorus are more dependent on stormflow, typically a minor component of total monthly streamflow. 
Table 15. Monthly and annual nutrient and suspended-sediment loads in streamflow from the Small Watershed (site SW1) for the period October 1989 through September 1991

[Mean streamflow in cubic feet per second; nutrient loads in pounds; suspended-sediment loads in tons]

\begin{tabular}{|c|c|c|c|c|c|c|c|}
\hline Month & Year & $\begin{array}{c}\text { Mean } \\
\text { streamflow }\end{array}$ & $\begin{array}{c}\text { Total } \\
\text { nitrogen }\end{array}$ & $\begin{array}{l}\text { Total nitrate } \\
\text { plus nitrite }\end{array}$ & $\begin{array}{l}\text { Total ammonium } \\
\text { plus organic } \\
\text { nitrogen }\end{array}$ & $\begin{array}{c}\text { Total } \\
\text { phosphorus }\end{array}$ & $\begin{array}{l}\text { Suspended } \\
\text { sediment }\end{array}$ \\
\hline \multirow[t]{2}{*}{ October } & 1989 & 6.54 & 8,770 & 6,040 & 2,730 & 831 & 217 \\
\hline & 1990 & 3.09 & 4,229 & 3,260 & 969 & 275 & 23 \\
\hline \multirow[t]{2}{*}{ November } & 1989 & 4.40 & 7,240 & 5,880 & 1,360 & 273 & 55 \\
\hline & 1990 & 5.11 & 9,760 & 6,310 & 3,450 & 1,050 & 1,050 \\
\hline \multirow[t]{2}{*}{ December } & 1989 & 2.69 & 4,420 & 3,760 & 660 & 167 & 19 \\
\hline & 1990 & 9.21 & 14,040 & 10,500 & 3,540 & 1,070 & 171 \\
\hline \multirow[t]{2}{*}{ January } & 1990 & 12.10 & 19,530 & 10,800 & 8,730 & 3,320 & 1,380 \\
\hline & 1991 & 9.78 & 14,150 & 12,200 & 1,950 & 422 & 68 \\
\hline \multirow[t]{2}{*}{ February } & 1990 & 8.77 & 10,260 & 8,780 & 1,480 & 315 & 47 \\
\hline & 1991 & 5.55 & 8,190 & 6,940 & 1,250 & 72 & 11 \\
\hline \multirow[t]{2}{*}{ March } & 1990 & 4.91 & 6,813 & 6,020 & 793 & 149 & 19 \\
\hline & 1991 & 7.44 & 10,910 & 8,920 & 1,990 & 251 & 43 \\
\hline \multirow[t]{2}{*}{ April } & 1990 & 6.67 & 8,790 & 6,860 & 1,930 & 286 & 44 \\
\hline & 1991 & 6.30 & 8,180 & 7,060 & 1,120 & 162 & 21 \\
\hline \multirow[t]{2}{*}{ May } & 1990 & 7.74 & 15,420 & 8,910 & 6,510 & 1,040 & 298 \\
\hline & 1991 & 4.09 & 5,650 & 4,600 & 1,050 & 173 & 41 \\
\hline \multirow[t]{2}{*}{ June } & 1990 & 7.57 & 14,530 & 5,610 & 8,920 & 1,470 & 1,800 \\
\hline & 1991 & 2.31 & 3,307 & 2,460 & 847 & 137 & 22 \\
\hline \multirow[t]{2}{*}{ July } & 1990 & 2.20 & 2,220 & 2,220 & 577 & 123 & 14 \\
\hline & 1991 & 2.11 & 1,640 & 1,640 & 2,570 & 528 & 270 \\
\hline \multirow[t]{2}{*}{ August } & 1990 & 5.03 & 4,680 & 4,680 & 2,850 & 732 & 251 \\
\hline & 1991 & 2.64 & 1,520 & 1,520 & 3,510 & 802 & 568 \\
\hline \multirow[t]{2}{*}{ September } & 1990 & 3.11 & 4,620 & 3,630 & 990 & 192 & 34 \\
\hline & 1991 & 1.41 & 1,799 & 890 & 909 & 309 & 62 \\
\hline \multirow[t]{2}{*}{ Mean annual } & 1990 & 5.96 & 9,230 & 6,100 & 3,130 & 742 & 348 \\
\hline & 1991 & 4.93 & 7,460 & 5,530 & 1,930 & 438 & 196 \\
\hline
\end{tabular}


Table 16. Monthly and annual nutrient and suspended-sediment loads in streamflow from the Nutrient-Management Subbasin (site NM5) for the period October 1989 through September 1991

[Mean streamflow in cubic feet per second; nutrient loads in pounds; suspended-sediment loads in tons]

\begin{tabular}{|c|c|c|c|c|c|c|c|}
\hline Month & Year & $\begin{array}{c}\text { Mean } \\
\text { streamflow }\end{array}$ & $\begin{array}{c}\text { Total } \\
\text { nitrogen }\end{array}$ & $\begin{array}{l}\text { Total nitrate } \\
\text { plus nitrite }\end{array}$ & $\begin{array}{l}\text { Total ammonium } \\
\text { plus organic } \\
\text { nitrogen }\end{array}$ & $\begin{array}{c}\text { Total } \\
\text { phosphorus }\end{array}$ & $\begin{array}{l}\text { Suspended } \\
\text { sediment }\end{array}$ \\
\hline \multirow[t]{2}{*}{ October } & 1989 & 1.06 & 1,249 & 807 & 442 & 134 & 31 \\
\hline & 1990 & .52 & 802 & 597 & 205 & 62 & 6 \\
\hline \multirow[t]{2}{*}{ November } & 1989 & .65 & 1,102 & 902 & 200 & 38 & 4 \\
\hline & 1990 & .70 & 1,101 & 799 & 302 & 112 & 17 \\
\hline \multirow[t]{2}{*}{ December } & 1989 & .28 & 484 & 386 & 98 & 28 & 3 \\
\hline & 1990 & 1.37 & 2,149 & 1,550 & 599 & 186 & 24 \\
\hline \multirow[t]{2}{*}{ January } & 1990 & 2.35 & 3,330 & 1,830 & 1,500 & 518 & 168 \\
\hline & 1991 & 1.82 & 2,838 & 2,450 & 388 & 93 & 14 \\
\hline \multirow[t]{2}{*}{ February } & 1990 & 1.68 & 1,949 & 1,760 & 189 & 26 & 3 \\
\hline & 1991 & 1.18 & 1,815 & 1,540 & 275 & 16 & 2 \\
\hline \multirow[t]{2}{*}{ March } & 1990 & .81 & 1,128 & 1,030 & 98 & 13 & 2 \\
\hline & 1991 & 1.26 & 1,936 & 1,600 & 336 & 39 & 6 \\
\hline \multirow[t]{2}{*}{ April } & 1990 & 1.06 & 1,457 & 1,060 & 397 & 78 & 12 \\
\hline & 1991 & 1.28 & 1,712 & 1,470 & 242 & 43 & 6 \\
\hline \multirow[t]{2}{*}{ May } & 1990 & 1.49 & 2,700 & 1,460 & 1,240 & 172 & 53 \\
\hline & 1991 & .90 & 1,255 & 1,000 & 255 & 49 & 10 \\
\hline \multirow[t]{2}{*}{ June } & 1990 & 1.47 & 2,480 & 1,230 & 1,250 & 296 & 88 \\
\hline & 1991 & .63 & 911 & 692 & 219 & 29 & 6 \\
\hline \multirow[t]{2}{*}{ July } & 1990 & .72 & 966 & 753 & 213 & 50 & 6 \\
\hline & 1991 & .66 & 986 & 547 & 439 & 92 & 21 \\
\hline \multirow[t]{2}{*}{ August } & 1990 & 1.02 & 1,615 & 927 & 688 & 156 & 20 \\
\hline & 1991 & .47 & 890 & 333 & 557 & 132 & 28 \\
\hline \multirow[t]{2}{*}{ September } & 1990 & .52 & 810 & 600 & 210 & 52 & 13 \\
\hline & 1991 & .36 & 393 & 239 & 154 & 42 & 38 \\
\hline \multirow[t]{2}{*}{ Mean annual } & 1990 & 1.09 & 1,606 & 1,062 & 544 & 130 & 34 \\
\hline & 1991 & .93 & 1,399 & 1,068 & 331 & 75 & 15 \\
\hline
\end{tabular}




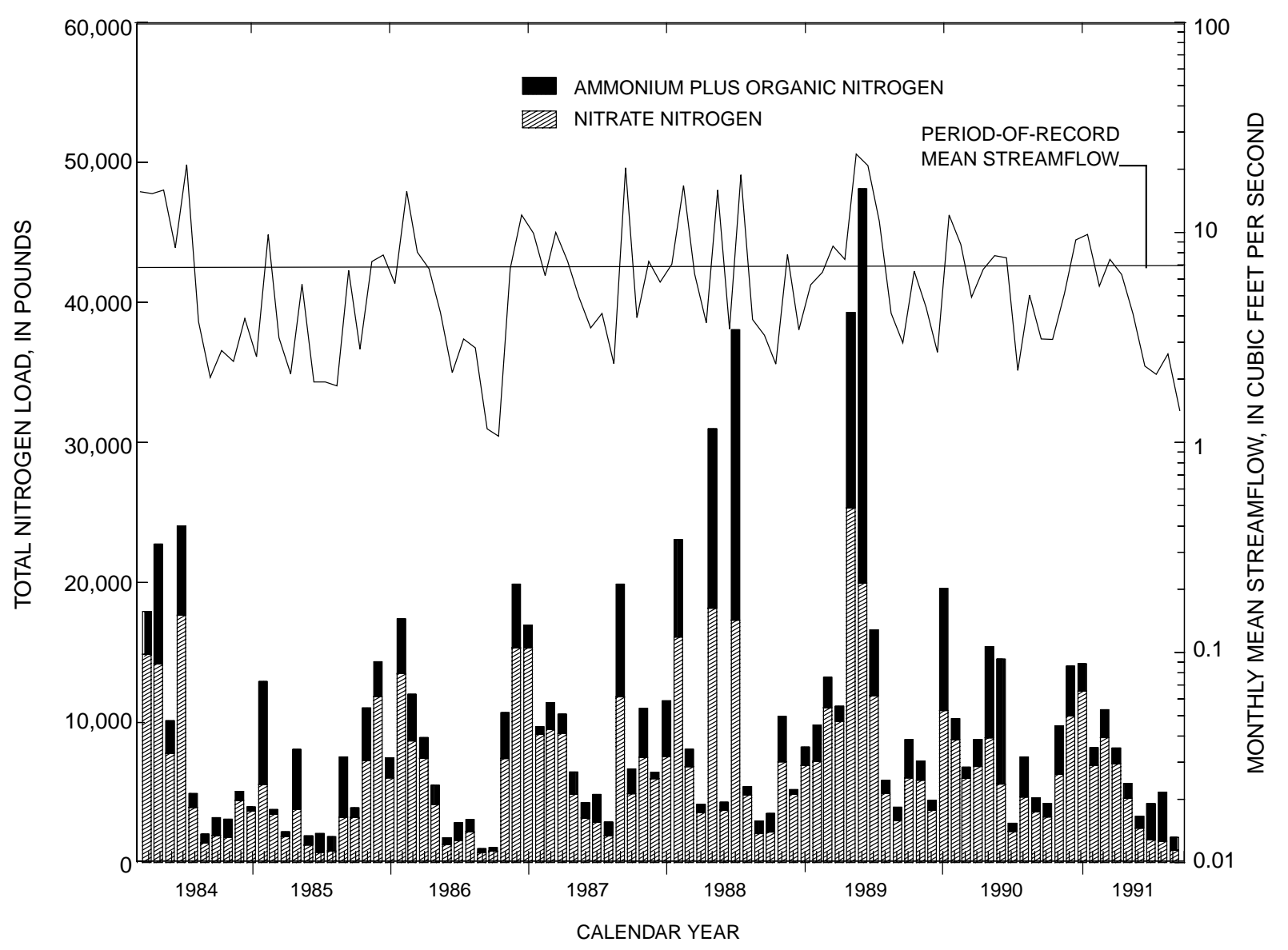

Figure 15. Monthly loads and monthly mean streamflow at site SW1 in the Small Watershed from April 1984 through September 1991. 


\section{Benthic Macroinvertebrates}

\section{by Michael D. Bilger, Biologist}

Sites within $300 \mathrm{ft}$ of NM1, NM5, and NC1 were sampled for benthic macroinvertebrates in October 1988 (fall) and May 1989 (midspring). A third round of sampling was completed in May 1991 at site NM1 and in April 1991 at sites NM5 and NC1. Tables 17 and 18 list taxa, counts, and EPT index values for Surber and kick screen samples, respectively.

Site NM1 was forested with oak, maple, and hickory forming much of the canopy. The stream was about $4 \mathrm{ft}$ wide and less than $1 \mathrm{ft}$ deep. The stream substrate was of a boulder-cobble composition with a visible sediment coating. The macroinvertebrate community was dominated by Ephemeroptera (mayflies), hydropsychid caddisflies, Plecoptera (stoneflies), the elmid beetle Stenelmis, and Chironomidae. Some 20 total taxa were collected by Surber sampler and 32 total taxa by the kick-screen method in 1991. A total of 56 taxa were collected by combining the collection methods over all 3 years.

Site NM5 was in open pasture with no canopy cover. The stream had a width of about $6 \mathrm{ft}$ and a depth of $1 \mathrm{ft}$. A variable layer of silt covered the substrate up to $6 \mathrm{in}$. in depth. The benthic community at site NM5 was indicative of a depositional habitat with Oligochaeta (aquatic earthworms), Chironomids, and Isopoda (aquatic sowbugs) representing the dominant taxa along with Turbellaria (flatworms), which were likely attracted by a suitable habitat and food source. Simuliidae (black fly larvae) were abundant where rock surfaces were not heavily silt covered. A total of 17 taxa were collected by the Surber sampler and 15 taxa by the kick screens in 1991. A combined total of 34 taxa were collected by both methods over all 3 years.

Site NC1 also was in open pasture with no appreciable canopy cover. The stream had a width of about $6 \mathrm{ft}$ and a depth of $1 \mathrm{ft}$. The substrate was covered with a layer of silt averaging $1 \mathrm{in}$. in depth. Aquatic earthworms, chironomids, black flies, and aquatic sowbugs dominated the benthic community with a total of 13 taxa collected by Surber sampler and 18 taxa by kick screens in 1991. A total of 35 taxa were collected by the two types of samplers over all 3 years.

An examination of the physiochemical and biological data at site NM1 revealed a very diverse benthic macroinvertebrate community with many "clean water" indicator taxa. Adverse effects by siltation or nutrient enrichment were not observed at this site. Site NM5, located about 1 mi downstream, however, did show a shift in the benthic community toward more "pollution tolerant" taxa representative of depositional-type habitats. The stoneflies were not present at this site and the numbers of mayfly and caddisfly taxa were reduced. The combination of increased siltation and nutrient concentrations were likely the cause of the drop in taxa considered "pollution intolerant." Site NC1 also showed the effects of siltation and increased nutrient loads, although not as severe as site NM5, because mayfly and caddisfly total taxa and numbers remained moderate. Conclusions from other comparisons within and among sites are as follows:

1. Macroinvertebrate samples collected in the fall were of a different species composition than the early to mid-spring samples. The mayfly and stonefly taxa were reduced in the fall collections; these life history responses, especially at site NM1, were likely independent of water-quality conditions.

2. Numbers of total taxa and individuals generally declined in spring 1991 compared with spring 1989 in the Surber collections indicating a possible change in water quality.

3. The EPT Index values for both collection methods at site NM1 ranged from 11 to 22 , at site NM5 from 1 to 3 , and at site NC1 from 1 to 6 . These values generally increase with improving water quality. 
Table 17. Benthic macroinvertebrates collected by Surber sampler in the Small Watershed [--, taxon not found in sample]

\begin{tabular}{|c|c|c|c|c|c|c|c|c|c|}
\hline \multirow[b]{2}{*}{ Taxa } & \multicolumn{3}{|c|}{ Site NM1 } & \multicolumn{3}{|c|}{ Site NM5 } & \multicolumn{3}{|c|}{ Site NC1 } \\
\hline & $\begin{array}{c}\text { October } \\
1988\end{array}$ & $\begin{array}{l}\text { May } \\
1989\end{array}$ & $\begin{array}{l}\text { May } \\
1991\end{array}$ & $\begin{array}{c}\text { October } \\
1988\end{array}$ & $\begin{array}{l}\text { May } \\
1989\end{array}$ & $\begin{array}{l}\text { April } \\
1991\end{array}$ & $\begin{array}{c}\text { October } \\
1988\end{array}$ & $\begin{array}{l}\text { May } \\
1989\end{array}$ & $\begin{array}{l}\text { April } \\
1991\end{array}$ \\
\hline \multicolumn{10}{|l|}{ Platyhelminthes } \\
\hline Turbellaria - flatworms & -- & -- & -- & 53 & -- & -- & 5 & -- & -- \\
\hline \multicolumn{10}{|l|}{ Tricladida } \\
\hline \multicolumn{10}{|l|}{ Planariidae } \\
\hline Cura & -- & -- & -- & 46 & -- & -- & 13 & 1 & -- \\
\hline Dugesia & -- & 2 & -- & -- & 141 & 19 & -- & -- & -- \\
\hline Nematoda - nematodes & -- & -- & -- & -- & -- & -- & -- & -- & 1 \\
\hline \multicolumn{10}{|l|}{ Annelida } \\
\hline Oligochaeta - aquatic earthworms & -- & -- & 1 & -- & -- & 180 & -- & -- & 30 \\
\hline Lumbricidae & 2 & 1 & -- & 5 & -- & -- & 4 & 2 & -- \\
\hline Tubificidae & -- & -- & -- & 55 & 52 & -- & 40 & 185 & -- \\
\hline Hirudinea - leeches & -- & -- & -- & 1 & 3 & -- & 15 & 1 & -- \\
\hline \multicolumn{10}{|l|}{ Glossiphoniidae } \\
\hline Helobdella & -- & -- & -- & -- & -- & 9 & -- & -- & -- \\
\hline \multicolumn{10}{|l|}{ Arthropoda } \\
\hline \multicolumn{10}{|l|}{ Chelicerata } \\
\hline Hydracarina - water mites & -- & -- & -- & -- & 2 & 1 & -- & -- & -- \\
\hline \multicolumn{10}{|l|}{ Crustacea-crustaceans } \\
\hline Ostracoda & -- & -- & -- & -- & 111 & 25 & -- & -- & -- \\
\hline \multicolumn{10}{|l|}{ Isopoda - aquatic sow bugs } \\
\hline \multicolumn{10}{|l|}{ Asellidae } \\
\hline Caecidotea & -- & -- & -- & 190 & 20 & 2 & 22 & 5 & 21 \\
\hline Decapoda - crayfish & -- & -- & 2 & -- & -- & -- & -- & -- & -- \\
\hline Cambaridae & -- & 3 & -- & -- & -- & -- & -- & -- & -- \\
\hline Orconectes & -- & -- & -- & -- & -- & -- & 1 & -- & -- \\
\hline \multicolumn{10}{|l|}{ Insecta } \\
\hline \multicolumn{10}{|l|}{ Ephemeroptera - mayflies } \\
\hline \multicolumn{10}{|l|}{ Baetidae } \\
\hline Baetis & 11 & 39 & -- & 1 & -- & 9 & 1 & 76 & -- \\
\hline \multicolumn{10}{|l|}{ Ephemerellidae } \\
\hline Ephemerella & -- & 43 & 14 & -- & 1 & -- & -- & 6 & -- \\
\hline \multicolumn{10}{|l|}{ Heptageniidae } \\
\hline Cinygmula & -- & 34 & -- & -- & -- & -- & -- & -- & -- \\
\hline Epeorus & -- & 9 & 1 & -- & -- & -- & -- & -- & -- \\
\hline Heptagenia & -- & -- & 2 & -- & -- & -- & -- & -- & -- \\
\hline Leucrocuta & -- & 6 & -- & -- & -- & -- & -- & -- & -- \\
\hline Stenonema & 5 & 18 & 4 & -- & -- & -- & -- & -- & -- \\
\hline \multicolumn{10}{|l|}{ Leptophlebiidae } \\
\hline Paraleptophlebia & 2 & 16 & 9 & -- & -- & -- & -- & -- & -- \\
\hline \multicolumn{10}{|l|}{ Siphlonuridae } \\
\hline Ameletus & -- & 3 & -- & -- & -- & -- & -- & -- & -- \\
\hline Odonata - dragon and damselfli & & & & & & & & & \\
\hline Coenagrionidae & & & & & & & & & \\
\hline Enallagma/Ischnura & -- & -- & -- & 1 & -- & 5 & -- & -- & 1 \\
\hline
\end{tabular}


Table 17. Benthic macroinvertebrates collected by Surber sampler in the Small Watershed-Continued

\begin{tabular}{|c|c|c|c|c|c|c|c|c|c|}
\hline \multirow{2}{*}{ Taxa } & \multicolumn{3}{|c|}{ Site NM1 } & \multicolumn{3}{|c|}{ Site NM5 } & \multicolumn{3}{|c|}{ Site NC1 } \\
\hline & $\begin{array}{c}\text { October } \\
1988\end{array}$ & $\begin{array}{l}\text { May } \\
1989\end{array}$ & $\begin{array}{l}\text { May } \\
1991\end{array}$ & $\begin{array}{c}\text { October } \\
1988\end{array}$ & $\begin{array}{l}\text { May } \\
1989\end{array}$ & $\begin{array}{l}\text { April } \\
1991\end{array}$ & $\begin{array}{c}\text { October } \\
1988\end{array}$ & $\begin{array}{l}\text { May } \\
1989\end{array}$ & $\begin{array}{l}\text { April } \\
1991\end{array}$ \\
\hline \multicolumn{10}{|l|}{ Arthropoda } \\
\hline \multicolumn{10}{|l|}{ Insecta } \\
\hline \multicolumn{10}{|l|}{ Plecoptera - stoneflies } \\
\hline \multicolumn{10}{|l|}{ Capniidae } \\
\hline Allocapnia & -- & -- & 1 & -- & -- & -- & -- & -- & -- \\
\hline Chloroperlidae & -- & 1 & -- & -- & -- & -- & -- & -- & -- \\
\hline Haploperla & -- & 3 & -- & -- & -- & -- & -- & -- & -- \\
\hline Suwallia-Sweltsa gr. & -- & 1 & -- & -- & -- & -- & -- & -- & -- \\
\hline \multicolumn{10}{|l|}{ Nemouridae } \\
\hline Amphinemura & -- & 1 & 7 & -- & -- & -- & -- & -- & -- \\
\hline \multicolumn{10}{|l|}{ Peltoperlidae } \\
\hline Peltoperla & -- & -- & 5 & -- & -- & -- & -- & -- & -- \\
\hline \multicolumn{10}{|l|}{ Perlodidae } \\
\hline Isoperla & -- & -- & 5 & -- & -- & -- & -- & -- & -- \\
\hline Isoperla holochlora & -- & 4 & -- & -- & -- & -- & -- & -- & -- \\
\hline Remenus & -- & 1 & -- & -- & -- & -- & -- & -- & -- \\
\hline \multicolumn{10}{|l|}{ Hemiptera - true bugs } \\
\hline \multicolumn{10}{|l|}{ Corixidae } \\
\hline Sigara & -- & -- & -- & -- & -- & -- & -- & -- & 1 \\
\hline \multicolumn{10}{|l|}{ Coleoptera - beetles } \\
\hline Dytiscidae & -- & -- & -- & 2 & 2 & -- & -- & -- & -- \\
\hline Agabus & -- & -- & -- & -- & -- & 4 & -- & -- & -- \\
\hline \multicolumn{10}{|l|}{ Elmidae } \\
\hline Dubiraphia & -- & 1 & -- & 1 & -- & -- & -- & -- & -- \\
\hline Stenelmis & -- & 61 & -- & 4 & 19 & -- & 3 & 1 & 3 \\
\hline \multicolumn{10}{|l|}{ Eubriidae } \\
\hline Ectopria & -- & -- & 2 & 1 & -- & -- & -- & -- & -- \\
\hline \multicolumn{10}{|l|}{ Haliplidae } \\
\hline Peltodytes & -- & -- & -- & -- & -- & 1 & -- & -- & -- \\
\hline Hydrophilidae & -- & -- & -- & -- & -- & -- & 1 & 1 & -- \\
\hline Berosus & -- & -- & -- & -- & -- & -- & -- & -- & 2 \\
\hline \multicolumn{10}{|l|}{ Trichoptera - caddisflies } \\
\hline \multicolumn{10}{|l|}{ Glossosomatidae } \\
\hline Glossosoma & 3 & -- & -- & -- & -- & -- & -- & -- & -- \\
\hline \multicolumn{10}{|l|}{ Hydropsychidae } \\
\hline Cheumatopsyche & 2 & 13 & -- & 3 & 2 & -- & 7 & 9 & -- \\
\hline Diplectrona & 33 & 20 & 39 & -- & -- & -- & -- & -- & -- \\
\hline Hydropsyche & -- & -- & -- & -- & -- & -- & -- & -- & 5 \\
\hline H. (Hydropsyche) & 16 & 15 & -- & -- & -- & -- & 42 & 19 & -- \\
\hline H. (Ceratopsyche) & 5 & 15 & -- & 9 & 1 & -- & 83 & 22 & -- \\
\hline \multicolumn{10}{|l|}{ Lepidostomatidae } \\
\hline Lepidostoma & -- & -- & 1 & -- & -- & 1 & -- & -- & -- \\
\hline Polycentropodidae & & & & & & & & & \\
\hline Polycentropus & 2 & 3 & -- & -- & -- & -- & -- & -- & -- \\
\hline
\end{tabular}


Table 17. Benthic macroinvertebrates collected by Surber sampler in the Small Watershed-Continued

\begin{tabular}{|c|c|c|c|c|c|c|c|c|c|}
\hline \multirow[b]{2}{*}{ Taxa } & \multicolumn{3}{|c|}{ Site NM1 } & \multicolumn{3}{|c|}{ Site NM5 } & \multicolumn{3}{|c|}{ Site NC1 } \\
\hline & $\begin{array}{c}\text { October } \\
1988\end{array}$ & $\begin{array}{l}\text { May } \\
1989\end{array}$ & $\begin{array}{l}\text { May } \\
1991\end{array}$ & $\begin{array}{c}\text { October } \\
1988\end{array}$ & $\begin{array}{l}\text { May } \\
1989\end{array}$ & $\begin{array}{l}\text { April } \\
1991\end{array}$ & $\begin{array}{c}\text { October } \\
1988\end{array}$ & $\begin{array}{l}\text { May } \\
1989\end{array}$ & $\begin{array}{l}\text { April } \\
1991\end{array}$ \\
\hline \multicolumn{10}{|l|}{ Arthropoda } \\
\hline \multicolumn{10}{|l|}{ Insecta } \\
\hline \multicolumn{10}{|l|}{ Trichoptera - caddisflies } \\
\hline \multicolumn{10}{|l|}{ Rhyacophilidae } \\
\hline Rhyacophila & -- & -- & 6 & -- & -- & -- & -- & -- & -- \\
\hline Rhyacophila carolina & 4 & 2 & -- & -- & -- & -- & -- & -- & -- \\
\hline Rhyacophila invaria gr. & 1 & 5 & -- & -- & -- & -- & -- & -- & -- \\
\hline \multicolumn{10}{|l|}{ Uenoidae } \\
\hline Neophylax & -- & 12 & -- & -- & -- & -- & -- & 1 & -- \\
\hline \multicolumn{10}{|l|}{ Diptera - true flies } \\
\hline \multicolumn{10}{|c|}{ Ceratopogonidae - biting midges } \\
\hline Bezzia gr. & -- & -- & -- & -- & 3 & -- & -- & -- & -- \\
\hline Chironomidae - midges & 3 & 137 & 4 & 40 & 919 & 273 & 73 & 331 & 645 \\
\hline \multicolumn{10}{|l|}{ Dixidae } \\
\hline Dixa & -- & -- & 3 & -- & -- & -- & -- & -- & -- \\
\hline \multicolumn{10}{|l|}{ Empididae - dance flies } \\
\hline Chelifera & -- & 1 & -- & -- & -- & -- & -- & -- & -- \\
\hline Hemerodromia & -- & 10 & -- & -- & 16 & 1 & -- & 9 & -- \\
\hline \multicolumn{10}{|c|}{ Psychodidae - sewage flies. } \\
\hline Telmatoscopus & -- & -- & 1 & -- & -- & -- & -- & -- & -- \\
\hline \multicolumn{10}{|l|}{ Simuliidae - black flies } \\
\hline Simulium & 1 & 2 & -- & 212 & 262 & 89 & 131 & 1,545 & 6 \\
\hline \multicolumn{10}{|l|}{ Tabanidae - deer flies } \\
\hline Tabanus & -- & -- & -- & -- & -- & 1 & -- & -- & -- \\
\hline Tipulidae - crane flies & 1 & -- & -- & -- & -- & -- & -- & -- & -- \\
\hline Antocha & -- & 7 & -- & -- & -- & -- & -- & 35 & 2 \\
\hline Hexatoma & -- & -- & 1 & -- & -- & -- & -- & -- & -- \\
\hline Limnophila & -- & -- & 1 & -- & -- & -- & -- & -- & -- \\
\hline Tipula & -- & 1 & -- & -- & -- & -- & -- & -- & -- \\
\hline \multicolumn{10}{|l|}{ Mollusca } \\
\hline \multicolumn{10}{|l|}{ Gastropoda - snails } \\
\hline Physidae & -- & -- & -- & 1 & -- & -- & -- & -- & -- \\
\hline Physa & -- & -- & -- & -- & 11 & 10 & -- & -- & -- \\
\hline Physella & -- & -- & -- & -- & -- & -- & 1 & 8 & -- \\
\hline Planorbidae & -- & -- & -- & 6 & 83 & -- & 2 & -- & -- \\
\hline Gyraulus & -- & -- & -- & -- & -- & 2 & -- & -- & 1 \\
\hline \multicolumn{10}{|l|}{ Pelecypoda - clams } \\
\hline \multicolumn{10}{|c|}{ Sphaeriidae - fingernail clams } \\
\hline Pisidium & -- & -- & -- & -- & -- & -- & -- & -- & 3 \\
\hline Total number taxa & 15 & 33 & 20 & 18 & 17 & 17 & 17 & 18 & 13 \\
\hline Total number individuals & 91 & 490 & 109 & 631 & 1,647 & 632 & 444 & 2,257 & 721 \\
\hline EPT Index value & 11 & 22 & 12 & 3 & 3 & 2 & 4 & 6 & 1 \\
\hline
\end{tabular}


Table 18. Benthic macroinvertebrates collected by kick screen in the Small Watershed [--, taxon not found in sample]

\begin{tabular}{|c|c|c|c|}
\hline \multirow[b]{2}{*}{ Taxa } & Site NM1 & Site NM5 & Site NC1 \\
\hline & $\begin{array}{c}\text { May 3, } \\
1991\end{array}$ & $\begin{array}{c}\text { April 18, } \\
1991\end{array}$ & $\begin{array}{c}\text { April 18, } \\
1991\end{array}$ \\
\hline \multicolumn{4}{|l|}{ Platyhelminthes } \\
\hline \multicolumn{4}{|l|}{ Turbellaria - flatworms } \\
\hline \multicolumn{4}{|l|}{ Tricladida } \\
\hline \multicolumn{4}{|l|}{ Planariidae } \\
\hline Dugesia & -- & 280 & 20 \\
\hline \multicolumn{4}{|l|}{ Annelida } \\
\hline Oligochaeta - aquatic earthworms & 1 & 120 & 20 \\
\hline \multicolumn{4}{|l|}{ Hirudinea - leeches } \\
\hline \multicolumn{4}{|l|}{ Glossiphoniidae } \\
\hline Helobdella & -- & 15 & -- \\
\hline \multicolumn{4}{|l|}{ Arthropoda } \\
\hline \multicolumn{4}{|l|}{ Crustacea-crustaceans } \\
\hline Ostracoda & -- & 39 & -- \\
\hline \multicolumn{4}{|l|}{ Isopoda - aquatic sow bugs } \\
\hline \multicolumn{4}{|l|}{ Asellidae } \\
\hline Caecidotea & -- & 26 & 76 \\
\hline Decapoda - crayfish & 1 & -- & 1 \\
\hline \multicolumn{4}{|l|}{ Insecta } \\
\hline \multicolumn{4}{|l|}{ Ephemeroptera - mayflies } \\
\hline \multicolumn{4}{|l|}{ Baetidae } \\
\hline Baetis & -- & 4 & 5 \\
\hline \multicolumn{4}{|l|}{ Ephemerellidae } \\
\hline Ephemerella & 170 & -- & 2 \\
\hline \multicolumn{4}{|l|}{ Heptageniidae } \\
\hline Epeorus & 11 & -- & -- \\
\hline Heptagenia & 20 & -- & -- \\
\hline Stenacron & 12 & -- & -- \\
\hline Stenonema & 38 & -- & -- \\
\hline \multicolumn{4}{|l|}{ Leptophlebiidae } \\
\hline Paraleptophlebia & 125 & -- & -- \\
\hline \multicolumn{4}{|l|}{ Siphlonuridae } \\
\hline Ameletus & 15 & -- & -- \\
\hline \multicolumn{4}{|l|}{ Odonata - dragon and damselflies } \\
\hline \multicolumn{4}{|l|}{ Coenagrionidae } \\
\hline Ischnura & -- & 5 & 1 \\
\hline \multicolumn{4}{|l|}{ Plecoptera - stoneflies } \\
\hline \multicolumn{4}{|l|}{ Capniidae } \\
\hline Allocapnia & 22 & -- & -- \\
\hline Chloroperlidae & & & \\
\hline Haploperla & 5 & -- & -- \\
\hline Nemouridae & & & \\
\hline Amphinemura & 76 & -- & 1 \\
\hline Peltoperlidae & & & \\
\hline Peltoperla & 10 & -- & -- \\
\hline Perlidae & & & \\
\hline Beloneuria & 1 & -- & -- \\
\hline Eccoptura & 3 & -- & -- \\
\hline
\end{tabular}


Table 18. Benthic macroinvertebrates collected by kick screen in the Small Watershed-Continued

\begin{tabular}{|c|c|c|c|}
\hline \multirow[b]{2}{*}{ Taxa } & Site NM1 & Site NM5 & Site NC1 \\
\hline & $\begin{array}{c}\text { May 3, } \\
1991\end{array}$ & $\begin{array}{c}\text { April 18, } \\
1991\end{array}$ & $\begin{array}{c}\text { April 18, } \\
1991\end{array}$ \\
\hline \multicolumn{4}{|l|}{ Arthropoda } \\
\hline \multicolumn{4}{|l|}{ Insecta } \\
\hline \multicolumn{4}{|l|}{ Plecoptera - stoneflies } \\
\hline \multicolumn{4}{|l|}{ Perlodidae } \\
\hline Isoperla & 21 & -- & -- \\
\hline \multicolumn{4}{|l|}{ Megaloptera - dobsonflies and alderflies } \\
\hline \multicolumn{4}{|l|}{ Sialidae } \\
\hline Sialis & 1 & -- & -- \\
\hline \multicolumn{4}{|l|}{ Coleoptera - beetles } \\
\hline \multicolumn{4}{|l|}{ Dytiscidae } \\
\hline Agabus & -- & 3 & 3 \\
\hline \multicolumn{4}{|l|}{ Elmidae } \\
\hline Dubiraphia & -- & -- & 1 \\
\hline Oulimnius & 2 & -- & -- \\
\hline Stenelmis & -- & -- & 11 \\
\hline \multicolumn{4}{|l|}{ Eubriidae } \\
\hline Ectopria & 2 & -- & -- \\
\hline \multicolumn{4}{|l|}{ Haliplidae } \\
\hline Peltodytes & -- & 3 & -- \\
\hline \multicolumn{4}{|l|}{ Hydrophilidae } \\
\hline Berosus & -- & -- & 2 \\
\hline \multicolumn{4}{|l|}{ Trichoptera - caddisflies } \\
\hline \multicolumn{4}{|l|}{ Hydropsychidae } \\
\hline Cheumatopsyche & -- & -- & 23 \\
\hline Diplectrona & 135 & -- & -- \\
\hline Hydropsyche & -- & -- & 68 \\
\hline \multicolumn{4}{|l|}{ Lepidostomatidae } \\
\hline Lepidostoma & 1 & -- & -- \\
\hline \multicolumn{4}{|l|}{ Limnephilidae } \\
\hline Apatania & 1 & -- & -- \\
\hline Hydatophylax & 1 & -- & -- \\
\hline \multicolumn{4}{|l|}{ Polycentropodidae } \\
\hline Polycentropus & 4 & -- & -- \\
\hline \multicolumn{4}{|l|}{ Rhyacophilidae } \\
\hline Rhyacophila & 16 & -- & -- \\
\hline \multicolumn{4}{|l|}{ Diptera - true flies } \\
\hline Ceratopogonidae - biting midges & 1 & -- & 2 \\
\hline Chironomidae - midges & 26 & 148 & 406 \\
\hline \multicolumn{4}{|l|}{ Dixidae } \\
\hline Dixa & 1 & -- & -- \\
\hline \multicolumn{4}{|l|}{ Empididae - dance flies } \\
\hline Hemerodromia & -- & -- & 4 \\
\hline \multicolumn{4}{|l|}{ Simuliidae - black flies } \\
\hline Simulium & 2 & 262 & 228 \\
\hline Stratiomyiidae & & & \\
\hline Stratiomys & -- & 1 & -- \\
\hline
\end{tabular}


Table 18. Benthic macroinvertebrates collected by kick screen in the Small Watershed-Continued

\begin{tabular}{|c|c|c|c|}
\hline \multirow[b]{2}{*}{ Taxa } & Site NM1 & Site NM5 & Site NC1 \\
\hline & $\begin{array}{c}\text { May 3, } \\
1991\end{array}$ & $\begin{array}{c}\text { April 18, } \\
1991\end{array}$ & $\begin{array}{c}\text { April 18, } \\
1991\end{array}$ \\
\hline \multicolumn{4}{|l|}{ Arthropoda } \\
\hline \multicolumn{4}{|l|}{ Insecta } \\
\hline \multicolumn{4}{|l|}{ Diptera - true flies } \\
\hline \multicolumn{4}{|l|}{ Tipulidae - crane flies } \\
\hline Hexatoma & 4 & -- & -- \\
\hline Limnophila & 1 & -- & -- \\
\hline Tipula & 1 & 2 & -- \\
\hline \multicolumn{4}{|l|}{ Mollusca } \\
\hline \multicolumn{4}{|l|}{ Gastropoda - snails } \\
\hline \multicolumn{4}{|l|}{ Physidae } \\
\hline Physa & -- & 53 & -- \\
\hline \multicolumn{4}{|l|}{ Planorbidae } \\
\hline Gyraulus & -- & 5 & -- \\
\hline Total number individuals & 730 & 966 & 874 \\
\hline Total number taxa & 32 & 15 & 18 \\
\hline EPT Index value & 20 & 1 & 5 \\
\hline
\end{tabular}

The benthic-macroinvertebrate data show the probable effects of increased siltation and (or) nutrient enrichment in the Little Conestoga Creek at sites NM5 and NC1 compared to site NM1. Along with the seasonal, yearly, and sample-collection method variations within and between sites was a decrease in the numbers of taxa and (or) numbers at all three sites in 1991 for the Surber collections. This was caused in a large part by the high numbers of oligochaetes, midges, and black flies in the 1989 collections and their reduction in 1991. The EPT Index values show better biological water quality at site NM1 than at sites NM5 and NC1; however, differences in the benthic community between sites NM5 and NC1 were small to nonexistent.

\section{SUMMARY AND CONCLUSIONS}

Agricultural-activity, soil-nutrient, hydrologic, water-quality, and benthic-macroinvertebrate data were collected in the Small Watershed drainage basin from October 1989 through September 1991 to determine the effects of nutrient management on surface-water quality. Agricultural-activity, soil-nutrient, hydrologic, and water-quality data were compared to data collected from April 1984 through September 1986 prior to the implementation of nutrient management and under a study supported by the U.S. Department of Agriculture's Rural Clean Water Program (RCWP).

The number of farms implementing nutrient management increased during the 2-year study period. Eleven new plans were prepared, increasing the percentage of agricultural land under nutrient management from 55 to 80 percent in the Small Watershed overall and from 15 to 40 percent in the Nonnutrient-Management Subbasin. The percentage of agricultural land with nutrient-management plans remained constant at 90 percent in the Nutrient-Management Subbasin. 
Reported nutrient applications to cropland in the Small Watershed totaled 923,800 lb of nitrogen and $278,900 \mathrm{lb}$ of phosphorus. Manure accounted for about 83 percent of the nitrogen and about 67 percent of the phosphorus applied to agricultural land in the Small Watershed. Reported nutrient applications to cropland in the Nutrient-Management Subbasin totaled 223,500 lb of nitrogen and 48,000 lb of phosphorus. Comparison of Nutrient-Management Subbasin applications to 1984-86 pre-nutrientmanagement applications showed a 7 percent decrease in nitrogen application and a 23 percent decrease in phosphorus application. A 44-percent reduction in the use of commercial fertilizer nitrogen accounted for the decrease in nitrogen applications. Because of uncertainty in the nutrient-application data, changes should be interpreted with caution.

Amounts of nitrate nitrogen in the top $4 \mathrm{ft}$ of soil ranged from 43 to $315 \mathrm{lb} /$ acre, and amounts of ammonia ranged from 20 to $95 \mathrm{lb} /$ acre. A substantial amount of nitrate and ammonia nitrogen was found in the limited number of soil samples collected from 4- to 8-ft depths. Amounts of orthophosphorus ranged from 3 to $23 \mathrm{lb} /$ acre. Comparison with RCWP data showed an average $100 \mathrm{lb} /$ acre reduction in nitrate nitrogen in soil samples from one of four sampling locations and a $14 \mathrm{lb} /$ acre reduction in orthophosphorus at one location.

Base-flow water quality had few significant step trends when compared to 1984-86 water quality. The only significant trend at site NM5, the Nutrient-Management Subbasin, was an increase in suspended sediment. At site NC1, the Nonnutrient-Management Subbasin, dissolved ammonium and suspended sediment decreased. No trends were detected at site SW1, the Small Watershed overall. The decrease in dissolved ammonium at site NC1 was the only significant step trend also reported by Koerkle and others (1996) for the first 3.5 years of nutrient management. Lack of consistent results in step-trend tests over time suggest that the trends may represent normal short-term variation in hydrologic and other environmental factors. Analysis of covariance of paired-subbasin data detected no change in the relation between dissolved nitrate plus nitrite concentrations in base flow between the Nutrient-Management and Nonnutrient-Management Subbasins.

During stormflow, mean concentrations for all constituents except dissolved nitrate plus nitrite were greater than median concentrations in base flow. At site SW1, the median of mean concentrations of total ammonium plus organic nitrogen, total phosphorus, and suspended sediment in stormflow were 480 percent, 860 percent, and 2,500 percent greater, respectively, than median concentrations in base flow. Stormflow is the primary source for loads of these constituents.

Mean constituent concentrations in stormflow were not reduced significantly. Mann-Whitney ranksum tests detected no significant change in 1989-91 mean concentrations of constituents in stormflow compared to 1984-86 mean concentrations in stormflow.

Benthic macroinvertebrate data showed a shift in the benthic community toward more "pollution tolerant" taxa when moving from sites NM1 to NC1 to NM5. Benthic communities at sites NM5 and NC1 showed the effects of siltation and increased nutrient loading; site NC1 was affected less severely. The EPT Index values ranged from 11 to 22 at site NM1, from 2 to 3 at site NM5, and from 1 to 6 at site NC1.

Implementation of nutrient management in the Small Watershed had no significant effect on surface-water quality. Few statistically detectable reductions in nutrient concentrations were found, and those reductions were not suggestive of an effect of nutrient management. Although nutrientmanagement plans were prepared for most farms in the Small Watershed, data collected in the NutrientManagement Subbasin indicated a poor correlation between a high percentage of farms with nutrientmanagement plans and a sustained decrease in nutrient applications to agricultural land over the 1986-91 nutrient-management period. Data collected during the entire 1986-91 nutrient-management period suggest a reduction in nitrogen input as large as the 30-percent reduction recorded from 1986-89 is needed to effect a $0.5 \mathrm{mg} / \mathrm{L}$ decrease in dissolved nitrate plus nitrite. 


\section{REFERENCES CITED}

Chambers, R.D., ed., 1991, The agronomy guide 1991-1992: University Park, Pa., Pennsylvania State University, College of Agriculture, $164 \mathrm{p}$.

Chichester, D.C., 1988, Evaluation of agricultural best-management practices in the Conestoga River Headwaters, Pennsylvania: Methods of data collection and analysis, and description of study areas: U.S. Geological Survey Open-File Report 88-96, 32 p.

Custer, B.H., 1985, Soil survey of Lancaster County, Pennsylvania: U.S. Department of Agriculture, Soil Conservation Service, $152 \mathrm{p}$.

Durlin, R.R., and Schaffstall, W.P., 1992, Water resources data for Pennsylvania, Water Year 1991, Volume 2, Susquehanna and Potomac River Basins: U.S. Geological Survey Water-Data Report PA-91-2, $374 \mathrm{p}$.

Fishel, D.K., Brown, M.J., Kostelnik, K.M., and Howse, M.A., 1992, Evaluation of agricultural bestmanagement practices in the Conestoga River Headwaters, Pennsylvania: Description and water quality of the Little Conestoga Creek headwaters prior to the implementation of nutrient management: U.S. Geological Survey Water-Resources Investigations Report 90-4131, 68 p.

Gerhart, J.M., and Lazorchick, G.J., 1984, Evaluation of the ground-water resources of parts of Lancaster and Berks Counties, Pennsylvania: U.S. Geological Survey Water-Resources Investigations Report 84-4327, $136 \mathrm{p}$.

Hall, D.W., Lietman, P.L., and Koerkle, E.H., 1996, Evaluation of agricultural best-management practices in the Conestoga River Headwaters, Pennsylvania: Effects of nutrient management on quality of surface runoff and ground water at a small carbonate-rock site near Ephrata, Pennsylvania, 1984-90: U.S. Geological Survey Water-Resources Investigations Report 95-4143, 59 p.

Helsel, D.R., and Hirsch, R.M., 1992, Statistical methods in water resources: New York, Elsevier Science Publishing Company Inc., 522 p.

Klemm, D.J., Lewis, P.A., Fulk, Florence, and Lazorchick, J.M., 1990, Macroinvertebrate field and laboratory methods for evaluating the biological integrity of surface waters: U.S. Environmental Protection Agency, EPA/600/4-90/030, 256 p.

Koerkle, E.H., Fishel, D.K., Brown, M.J., and Kostelnik, K.M., 1996, Evaluation of agricultural bestmanagement practices in the Conestoga River Headwaters, Pennsylvania: Effects of nutrient management on water quality in the Little Conestoga Creek headwaters, 1983-89: U.S. Geological Survey Water-Resources Investigations Report 95-4046, 49 p.

Loper, W.C., Durlin, R.R., and Schaffstall, W.P., 1991, Water resources data for Pennsylvania, Water Year 1990, Volume 2, Susquehanna and Potomac River Basins: U.S. Geological Survey Water-Data Report PA-90-2, 274 p.

Pennsylvania Department of Environmental Resources, 1988, Standardized biological field collection methods: Harrisburg, Pa., Bureau of Water Quality Management, 35 p.

Pettyjohn, W.A., and Henning, R., 1979, Preliminary estimate of ground-water recharge rates, related to streamflow and water quality in Ohio: The Ohio State University Department of Geology and Mineralogy Project Completion Report no. 522, 323 p.

Porterfield, G., 1972, Computation of fluvial-sediment discharge: U.S. Geological Survey Techniques of Water Resources Investigations, book 3, chap. C3, 66 p.

Spooner, Jean, Maas, R.P., Dressing, S.A., Smolen, M.D., and Humenik, F.J., 1985, Appropriate designs for documenting water quality improvements from agricultural NPS control programs, in Perspectives on Nonpoint Source Pollution: U.S. Environmental Protection Agency, EPA 440/5-85-001, p. 30-34.

U.S. Environmental Protection Agency, 1996, Drinking water regulations and health advisories: Washington, D.C., Office of Water, EPA 822-R-96-001, 11 p. 